\title{
Formation
}

Nordic Journal of Art and Research

ISSN: 1893-2479

www.artandresearch.info

\section{Relasjonen estetikk - epistemologi - etikk og fagdidaktikk. Et semiotisk-kommunikativt perspektiv på estetikk og utdanning}

\author{
Sigmund Ongstad ${ }^{1}$ \\ Fakultet for lærerutdanning og internasjonale studier, \\ Høgskolen i Oslo og Akershus, Oslo
}

\begin{abstract}
Sammendrag: Artikkelen tar mål av seg å vise at det hersker en indre sammenheng, på den ene siden mellom en rekke ulike kommunikative og didaktiske aspekter som kan samles under nøkkelbegrepene estetikk, epistemologi og etikk. På den annen side fremholdes det at det eksisterer en intern dynamikk mellom form, innhold og handling i enhver kulturell ytring, og at denne triaden utgjør grunnelementet $\mathrm{i}$ en rekke kjente triader innen filosofi og utdanning. Selv om teksten hovedsakelig argumenterer på et generelt nivå ved å sammenføre ulike teoretiske syn fra ulike kilder, baserer den seg også på flere empiriske studier av undervisning, kunnskap og læring. Selv om det sentrale fokus er på forholdet mellom de nevnte triadene, vies forholdet mellom estetikk og kommunikasjon særlig oppmerksomhet, spesielt i tilknytning til utdanning og fag-/didaktikk. Artikkelen drøfter først de mest sentrale begrepene og deres komplementære og følgelig problematiske natur. Videre presenteres og diskuteres to historisk viktige tekster som har forsøkt å håndtere disse forholdene. Dernest hevdes det at for å forstå triadenes innvirkning på forskeres faglige og vitenskapelige posisjonering, så bør teorirammen utvides fra språk i mer snever forstand til semiotikk. Siste del gir så et oversyn over og forklarer i detalj en rekke systemiske sammenhenger mellom presenterte nøkkelbegreper. Deretter gjøres korte evalueringer av begrepsrammeverket. Til slutt gis en rekke referanser til flere empiriske studier av triader i ulike utdanningskontekster, før artikkelens hovedideer oppsummeres.
\end{abstract}

Emneord: Epistemologi, estetisk teori, etikk, fagdidaktikk, kommunikative triader, kontekst, kunnskapsteori, semiotisk kommunikasjonsteori, sjangrer, ytringer

\footnotetext{
${ }^{1}$ Høgskolen i Oslo og Akershus, Fakultet for lærerutdanning og internasjonale studier, Postboks 4 St. Olavs plass, 0103 Oslo. E-post: sigmund.ongstad@hioa.no
} 


\section{Fokus og avgrensning}

Siktemålet med denne artikkelen er ikke å forsøke å definere hva estetikk isolert sett er eller burde være, men å vise mulige konsekvenser et bredt semiotisk, teoretisk kommunikativt utgangspunkt kan ha for en mer grunnleggende forståelse av relasjonen mellom estetikk, epistemologi og etikk mer generelt og følgelig for estetikk spesielt. Selv om fremstillingen tidvis beveger seg på et allment nivå, er hovedfokus likevel avgrenset til relasjonens og estetikkens potensielle betydning for felter som fagdidaktisk og pedagogisk forskning, eller utdanningsforskning om en vil.

En hovedutfordring for estetikk knyttet til utdanning og utdanningsvitenskap har vært en historisk tendens til å definere estetikk som en delvis lukket kategori (Kelly, 1998). 'Estetikken' har derfor ofte opptrådt i bestemt form entall, eller kanskje enda mer typisk, som selvstendig hovedaspekt i klart avgrensbare dyadiske forbindelser, som f.eks. den estetiske dimensjons relasjon til viten og vitenskap (Sørensen, 1999; Kragh, 1999; Flannery, 1991). Sagt på en annen måte, hovedvekten har vært lagt dels på teoretisering av form per se eller også på hvilken rolle form spiller i relasjonen form/innhold:

The Swedish Committee for Teacher Education (SOU 1999:63), for example (...) noted that knowing and aesthetic expression are often looked upon as opposite instead of supplementing aspects of learning. The members introduced the concept "aesthetic learning processes" (ibid.) to denote learning that integrates both aspects (Lindström, 2009:62).

Det har imidlertid ikke manglet opposisjon mot tradisjonelle en- og todimensjonale tenkemåter. I perioder har kunst- og formingsfagene, som en lang rekke andre fag, vært forsøkt innrettet mot bl.a. politikk, bruk, funksjon, kommunikasjon, religion og kontekst; en har søkt allianse med en etisk dimensjon (Thavenius, 2002; Leksikon for det 21. århundrede, 2013) eller som Wittgenstein skal ha ytret: (...) ethics and aesthetics are one (Levinson, 1998, s. 1). Og innen utdanning har estetikk, ofte på vikende front, altså måttet kjempe mot en sterk kognitiv interesse, altså en kunnskapsteoretisk eller epistemologisk dimensjon.

En rekke fremstillinger ser triaden det skjønne, det sanne og det rette som det mest overordnede, gjennomgående tema i filosofihistorien (O'Hear, 2000; Svendsen og Säätelä, 2004). For noen utgjør forholdet mellom dem nærmest definisjonen av filosofi (Thielst, 2001). Det er nettopp innen filosofi som felt at en først møter en begrunnet forestilling om estetikk som selvstendig begrep, navnlig hos Baumgarten på 1750-tallet (Kjørup, 1999:41). Dras linjen til vår egen tid finnes det imidlertid fortsatt en viss skepsis vis-à-vis den forankring begrepet estetikk dermed fikk:

Begrebet «æstetik» er ikke gammelt. Det stammer fra midten af 1700 tallet. Omtrent på samme tid får ordet «kunst» den betydning, det har i dag. Det er ingen tilfældighed. Det er netop den filosofiske videnskab «æstetik», der definerer kunsten som den skønne eller frie kunst - adskilt fra andre menneskelige færdigheder og gøremål. Den søger at forene to strenge i den filosofiske tradition siden antikken: Teorien om det skønne og teorien om kunstarterne. Derfor bliver «æstetik» oftest gengivet med «læren om det skønne i kunst og natur». Denne definition lader allerede ane vanskelighederne med denne videnskab (Leksikon for det 21. århundrede 2013, 'estetikk').

Men det er også innen filosofien, kanskje først med Kant, som raskt tok i bruk Baumgartens estetikk-begrep, at det skjer en kritisk vurdering av nettopp de tre hovedaspektene, eller med Kants ord i norsk oversettelse, den rene fornuft, den praktiske fornuft og dømmekraften (Kant, 1987/1790). Kanskje en bør legge til at $\mathrm{i}$ vår egen tid, som noen har karakterisert som postmoderne, har det blitt lansert nærmest eksistensialistiske oppfatninger av estetikk, hvor formen tenderer mot å bli selve 'Meningen':

Considering Nietzsche's deep influence on Foucault, it is not surprising that the phrase 'aesthetics of existence' can be traced back to Nietzsche's The Birth of Tragedy (Nietzsche 1967), which develops an 
'aesthetic justification of existence' - a fundamental attitude towards life which issues the assumption that "life is something amoral" (ibid.: section 5) (Wicks, 2001, s. 153).

En slik, nærmest 'monadisk rendyrking' kan en også iaktta på det epistemologiske feltet, f.eks. som essensialisme og på det etiske området, som universalisme. Men særlig det siste tiåret har det på den annen side kommet flere publikasjoner som insisterer på et bredt kommunikativt og/eller et eksplisitt semiotisk perspektiv i studiet av kunst, medier og estetikk (Stjernfeldt og Thyssen, 2000; Elf, 2009; Hausken 2009; Kress, 2010). Kanskje en også kunne trekke frem begrepet relasjonell estetikk, en estetisk teori som betrakter kunstverk på basis av de ulike mellom-menneskelige relasjoner de representer og etablerer (Bourriaud, 2007). Likevel, så sent som rundt årtusenskiftet hadde en presumptivt autoritativ kilde som Routledges estetikk-leksikon verken diskurs eller semiotikk som oppslagsord, og begreper som kommunikasjon og sjanger fantes ikke engang i stikkordsregisteret (Gaut og Lopes, 2001).

\section{Fra evolusjonært til kulturelt syn på form som kommunikativt aspekt}

Det er neppe stor uenighet om at form spiller en sentral rolle i evolusjon eller at form biologisk sett kan knyttes direkte til handling, at altså form har en grunnleggende funksjon for utvikling av liv (Hoffmeyer, 1994). Ved utvikling av symbol- og kommunikasjonssystemer både blant dyr og mennesker kan en dessuten finne semiotiske koblinger mellom gitte strukturer og gitte referanser (Finnegan, 2002). Kommunikasjon i bredest mulig forstand kan derfor ses som en primær prosess, drivkraft eller mekanisme, først i evolusjon og siden i kulturell utvikling. Om en altså anlegger et biosemiotisk perspektiv på kultur, finnes allerede de tre nødvendige hovedkonstituentene for kommunikasjon i naturen, som strukturert form, referensielt innhold og funksjonsrettet handling (Sebeok, 1991). Og de kan opptre som ett, som et dynamisk tegn (Peirce, 1994). Om en dermed definerer kommunikative ytringer nettopp som dynamiske tegn, vil de følgelig måtte bestå av de uadskillelige, gjensidig definerte aspektene form-innhold-bruk eller struktur-referanse-handling om en vil (Ongstad, 2004a). Koblingen blir altså selve definisjonen av kommunikasjon, og de tre aspektene utgjør altså samlet de minst tre nødvendige konstituentene i etablering av kommunikative ytringer. De tre aspektene vil dessuten alltid opptre i en dynamisk kontekst av tid og rom (sted) og de vil ytres og oppfattes i relasjon til ulike kommunikative forventninger, dvs. bestemte abstrakte, immanente former for kommunikasjon, som f.eks. sjangre og diskurser (Ongstad, 1996, 2002a, 2002b, 2010 og 2012a).

Det er som en forlengelse av en slik evolusjonsgenerert kommunikasjon en kan forstå estetikk i bred forstand og et toretisk rammverk for relasjonen estetikk - epistemologi - etikk (Ongstad, 2007a og 2007b). Det kan legges til grunn rent generelt og mer spesifikt $i$ forhold til utdanning og utdanningsforskning, siden utdanning favner om et bredt spekter av fagtyper som legger ulik vekt på de tre hovedaspektene (Ongstad, 2004). Det understrekes at det da ikke vil dreie seg om å utmynte bestemte metoder, men å etablere en generalisert referanseramme med metodologisk relevans for utdanningsvitenskap (Ongstad, 1999, 2007a, 2007b og 2013a). Ved dessuten å se ytringer i utdannings- og forskningssystemet som kommunikativt sett semiotiske, åpnes det i tillegg for en mer generell og følgelig også en mer multimodal, tverr- og flerfaglig referanseramme (Jensen, 1995; Elf, 2009 og Ongstad, 2012b). Denne artikkelen er derfor et relativt ambisiøst forsøk på å vise hvordan språk, semiotikk og kommunikasjon etablerer prinsipielle forskjeller mellom ulike fag- og vitenskapstradisjoner. Disse kan i sin tur ha relevans for analyser og studier av fag og utdanninger, særlig med henblikk på relasjonen estetikk - epistemologi - etikk.

Det ambisiøse ligger på flere plan. For det første dreier det seg om å finne et egnet teoretisk grunnlag som det kan diskuteres ut fra på tvers av faggrenser. For det andre ligger ambisjonen i at den 
teoretiske tilnærmingen likevel kan skje med utgangspunkt $i$ et relativt enkelt utgangspunkt, nemlig et komplementært, nærmest klassisk kommunikasjonstriangel, hvor en starter med å skille mellom ytringers substansielle form, semantiske innhold og bruksmessige funksjon, dvs. nokså likt det en gjør i nordiske skolers språkundervisning, og videre hvordan disse aspektene påvirkes av ytrernes og fortolkernes bruk av komplekse, diskursive sjangersystemer (Ongstad, 1997). Selv om en slik forståelse nok er mer kompleks i sine videre konsekvenser enn en enkel tredeling tilsynelatende kan gi inntrykk av, gir den samtidig en umiddelbar enkelhet som studenter, og kanskje også elever skulle kunne forstå (Ongstad, 1996). Denne tilgangen åpner i sin tur for den tredje og kanskje mest sentrale ambisjonen, nemlig at en semiotisk forståelsesramme som setter relasjonen estetikk - epistemologi etikk i sentrum, ikke bare har teoretisk, forskningsmessig interesse. Kanskje kan den også fungere som et praktisk tenke- og referanseredskap for refleksjon over, det vil si didaktisering av eget fagområde, som når en f.eks. spør studenter, hva gjør egentlig teksten din eller, hvilken funksjon har det estetiske element i skolefagene? (Ongstad, 2006a).

Når formenes, referansenes og handlingenes verdi gjøres til gjenstand for faglige undersøkelser, har en å gjøre med henholdsvis estetikk, epistemologi og etikk. Form knyttes i utgangspunktet primært til ytreren, til selv, referanse primært til innhold, til verden og funksjon primært til handling, til andre eller samfunn om en vil (Habermas, 1988). En ytrings sammenfattede gyldighet kan følgelig ses som på én gang subjektiv, objektiv og intersubjektiv hvor kriteriene vil være henholdsvis sanndruhet, sannhet og riktighet ('retthet') (Habermas, 1988). For å vurdere sanndruhet, må ytringen vurderes som symptom på ytrerens 'egentlige intensjon'. For å vurdere sannhetsgehalten må ytringen vurderes som symbol for et fenomen, og for å vurdere retthet må ytringen ses som signal til andre (eller 'noen') (Bühler, 1934).

Filosofi som fagfelt tenderer som nevnt mot å favne (minst) alle de tre feltene, samt deres innbyrdes forhold. Estetikk, epistemologi og etikk har derfor ofte, hver for seg, først og fremst forsøkt å fastholde h.h.v. hva (den gode) form er, hva (den sanne) referanse er og hva den (gode) handling er (Hernadi, 1995). Men samtidig erkjenner en gjerne at slike spørsmål ikke kan besvares (faglig og vitenskapelig tilfredsstillende) uten å avklare sammenhengen grunnelementet inngår i (Habermas, 1988). Noe forenklet kan en kanskje si at for estetikk kan grunnelementet, undersøkelsesobjektet i utgangspunktet være uttrykk (eng. expression, ty. Ausdruck), for epistemologi referensielt eller proposisjonelt innhold (eng. proposition, ty. Darstellung) og for etikk handling (eng. act, ty. Appell) (Bühler, 1934). Men alle tre fagfeltene vil måtte avklare mulige konsekvenser av innvirkning fra grunnelementer på de andre feltene. Med andre ord må en på alle tre feltene håndtere relasjonen subjektivitet - objektivitet - normativitet i kommunikative ytringer nærmest som et system av stadig vekslende vektorer (Ongstad, 2013a).

Siden faginnholdet $\mathrm{i}$ utdanningssystemet selv er og stammer fra ulike diskursive, semiotiske ytringer, vil utdanningsfagene på en eller annen måte også måtte forholde seg til det kommunikative trilemmaet som er beskrevet ovenfor (Ongstad, 2004a). Historisk har fag, profesjoner og kulturfelt helt eller delvis nettopp blitt inndelt etter hvilken funksjon de har fått, hatt eller tatt i den kulturelle re/produksjonen av samfunn, prototypisk f.eks. fagene forming, naturfag og kristendomskunnskap eller altså samfunnsfeltene kunst, vitenskap og religion (Habermas, 1998; Ongstad, 2010).

Noe forenklet har enkeltfeltene både innen filosofi og utdanning skiftet mellom monadiske, dyadiske og triadiske løsninger (Peirce, 1994; Ongstad, 1997). Monadiske, eller kanskje en skulle si monolittiske løsninger preges av isolering av aspektene ren estetikk, egentlig vitenskap eller universell etikk. Langt vanligere er dyadiske kombinasjoner av to hovedaspekter, jf. titler som AEstetik og logik (Holmgaard, 1999), Aesthetics and Ethics (Levinson, 1998) og Morality and Objectivity (Honderich, 
1985). Relativt få har på vitenskapelig/vitenskapsteoretisk grunnlag forsøkt å utrede eller å koble selve triaden, på tross av at det finnes en lang tradisjon for å etablere triader f.eks. innen retorikk (Aristoteles), filosofi (Kant), litteraturteori (Bakhtin), samfunnsteori (Habermas), antropologi (BenAmos) språkfilosofi og språkvitenskap (Bühler og Halliday) og utdanning (Pestalozzi og Steiner).

Kants tre berømte kritikker antar, når de ses $i$ sammenheng, delvis paradoksets karakter. Som jeg pekte på ovenfor må verdi og gyldighet for og på de tre feltene vurderes kritisk. Når de isoleres rent analytisk er hver av dem å betrakte som abstrakte eller konstruerte. Det er først når de ses i sammenheng i virkelige (kon-)tekster og situasjoner at de kan inngå i en mulig helhet. Paradokset består $\mathrm{i}$ at en må bestrebe seg på se en større helhet, men er avhengig av å forstå delene ('den hermeneutiske sirkel'). Men å forstå 'helhet' fullt ut gjennom summering av delene ses av de fleste kulturteoretikere som en umulighet. Kants livsoppgave kan imidlertid sies å ha vært den kritiske vurdering, ikke nødvendigvis å skulle føre aspektene sammen: "We can reduce all the powers of the human mind, without exception, to these three: the cognitive power, the feeling of pleasure and displeasure, and the power of desire (...) to bring unity into that diversity of powers (...) is futile (Kant, 1987, s. 394-395)." Likevel utgjør kritikkene (dvs. filosofien) en form for system eller et 'sett':

In conclusion, then, it is indeed the power of judgement, but above all the aesthetic power of judgement, i.e. the power of judgement as unaided by reason, that is responsible for the mediation between the "world" of the first Critique and the "world" of the second Critique by which the three Critiques come to form a system (Pluhar, 1987, s. civ).

Senere har flere forsøkt på ulike former for sammenføring, med mer eller mindre eksplisitt referanse til Kant, med vekslende utgangspunkter og hensikter, som f.eks. Peirce, Bühler, Bakhtin og Habermas. Forsøk på slik systembygging eller helhetstenkning har til dels fått hard medfart av kritikere, både av spesialister innen områdene estetikk, epistemologi og etikk, men i senere tid særlig av poststrukturalister og dekonstruksjonister (Grant, 2007). Det som er felles for de fire nevnte er kanskje ikke at de vil etablere grand theory, men snarere at de vil undersøke systemiske sammenhenger mellom aspekter i tegn, språk, ytringer og kommunikasjon og som gjør at en tross usikkerhet kan bli (tilstrekkelig) forstått. En systemisk teori kan sies å preges av en viss grad av åpenhet eller tillate en viss dynamikk i systemet.

\section{Didaktisk-kommunikative posisjoner}

Om en nå bringer den triadiske problematikken over på utdanningens område, kan en på sett og vis si at en står overfor en rekke didaktiske dilemmaer, eller trilemmaer om en vil. For lærerutdannere, lærerstudenter og elever f.eks. kan en innta kvalitativt sett ulike posisjoner for de ulike 'rollene' det kan være tale om. Lærerutdannere ønsker kanskje å prioritere didaktisk refleksjon, ikke bare i sine egne fags innhold, men også når det gjelder understøttelse av lærerstudenters praksis. Lærerstudenter vil kanskje fokusere mer på aktivitet, på det som planlegges, utføres og gjennomføres. Det kan dreie seg om å ha et praktisk grep på tingene, "kjøre et opplegg" (Mellin-Olsen, 1991), få elevene til å arbeide, få til aktivitet. For mange elever derimot er kanskje skolen i utgangspunktet mer et sted en må være, et sted hvor selv og kropp skal (over-)leve, et sted hvor følelser utfordres, enten ved at en forventes å kontrollere dem eller ved at en gir seg over til gode og vonde følelser (Ongstad, 2005).

Kommunikativt sett dreier det seg i ovennevnte tre stereotypiske eksempler om prioritering av eller fokusering på (henholdsvis) det referensielle, det funksjonelle og det emosjonelle eller på tenkning, handling og opplevelse om en vil (Ongstad, 2004; Hiim og Hippe, 1998). Men selvsagt har både lærere og lærerutdannere parallelt følelser også som didaktisk sett er helt sentrale. Og selvsagt tenker både elever og lærerstudenter over hva de foretar seg og hva undervisning handler om, og ikke 
minst er både elever og lærerutdannere aktive under undervisningsprosessene på én og samme gang. Likevel vil den 'arbeidsdelingen' som de ulike fokusene eller prioriteringene representerer kunne skape grunnleggende didaktiske funksjoner og dysfunksjoner. Det rent kunnskapsrelaterte delfeltet lærerutdannere utvikler kan ses som didaktisk epistemologi. Vurdering av hensikt, nytte og verdi av det undervisere og andre iverksetter kan kalles en didaktisk etikk, og den emosjonelle dimensjonen blir utgangspunkt for en didaktisk estetikk. Jeg velger disse tre uttrykkene mest for å bevisstgjøre at filosofi og vitenskapsteori allerede har etablert prinsipiell tenkning rundt disse kjerne-begrepene og relasjonene mellom dem, og fordi fagdidaktikk på ulike undervisningsnivåer i lærerutdanning burde kunne trekke veksler på denne innsikten.

Denne klassiske tredelingen kommer jeg tilbake til i flere omganger, men det er viktig først å understreke at den prinsipielt sett alltid vil være komplementcer på en kompleks måte. Det vil si at i et kommunikasjonsperspektiv forutsetter og definerer de tre hovedaspektene hverandre gjensidig og er likeverdige, eller for å bruke et begrep fra Roman Jakobson, teorien oppfatter ikke noen av de tre aspektene i utgangspunktet som dominant. Estetikk, epistemologi og etikk er altså like mye åpne relasjoner som mer avgrensede dimensjoner fordi de inngår som hovedkonstituenter i faglige vurderinger og kvalifiseringer av kommunikative ytringer. De innbyrdes forholdene er imidlertid delikate, både i teorien, og enda mer i praksis (Halliday, 1994; Martin, 1997).

I det følgende belyses derfor først estetikk i relasjon til epistemologi. Deretter følger noen punkter, nærmest i påstands form, om relasjonen(e) estetikk, epistemologi og etikk som grunnlag for didaktikk. Det rent kunnskapsmessige eller kunnskapens forhold til det sosiale tas ikke opp i denne sammenheng, da det allerede har en ganske dominerende plass innen mange didaktikker og fagdidaktikker i nordiske lærerutdanninger (jf. en rekke kontrastive fremstillinger av Piagets og Vygotskys arbeider). Poenget her er snarere å relatere de tre områdene eller aspektene innbyrdes og vise hvordan de er sentrale for fag-/didaktikk og å vise hvorfor en triadisk, det vil si en kommunikativ semiotikk, er direkte koblet til nettopp denne sentrale triaden. Det legges likevel mer vekt på estetikk enn på epistemologi og etikk.

\section{Estetikk som epistemologiens utfordrer i pedagogikken?}

Jeg fokuserer i fortsettelsen på to relativt kjente arbeider som tar opp forholdet mellom estetikk og kunnskap: Eisner (1985) og Løvlie (1990). Eisner fordi han lenge har øvd innflytelse på utdanningstenkning både internasjonalt og i Skandinavia (Lindström, 2009) og Løvlie fordi han i en nordisk kontekst gjennom flere tiår har vært en tydelig talsmann, ikke bare for estetikkens, men også for filosofiens betydning for pedagogisk tenkning. De to er også valgt av en annen grunn. De hører til et mindretall som drøfter forholdet estetikk/kunnskap også i relasjon til semiotikk, språk og kommunikasjon. Gjennomgangen vil være vennlig kritisk. Vennlig fordi artiklene synes å peke i riktig retning, kritisk fordi det kan synes å være visse mangler ved argumentasjonen.

Elliot Eisner, som lenge har vært en kjent advokat for det syn at fornuft og følelse, kunst og vitenskap ikke må holdes adskilt, oppsummerer i artikkelen Mind as Cultural Achievement sine utlegninger om erfaring som 'førverbal' på følgende vis:

First, the sensory systems make it possible to contact and portray the world in different ways. I have called these modes of portrayal 'forms of representation'.

Second, these forms of representation are available in the culture at large and function as means through which we conceptualize, express and recover meaning.

Third, to become literate in a wide sense means more than to be able to read, write or cipher. It means being able to use a variety of forms of representation for conceptualizing, expressing and recovering meaning. 
Fourth, since each form of representation emphasizes the use of different sensory systems and employs a different syntax, the kind of meaning that each provides is unique. What can be expressed in one form is not expressable in another.

Finally, at present, schools neglect the development of literacy in many forms of representation that are available in the culture. This neglect denies children access to meanings that are specific to particular forms, and adversely affects the kinds of meanings they can express in the forms that they are taught in schools (Eisner, 1985,s. 171).

Hvilket begrep mener så Eisner en kan dekke disse representasjonsformene? Han dveler et øyeblikk ved 'semiotics', men finner det for fremmed for dagligtalen og hverdagsforståelsen, og han ønsker derfor heller å utvide begrepet 'språk' slik at det dekker andre måter å mene på enn den rent verbale. Selv ser jeg på tendensen til at 'språk' skal innbefatte (alle) andre meningsformer som mindre heldig, da ikke bare hos Eisner, men også mer generelt. Riktignok er uttrykk som filmspråk, tonespråk og bildespråk ikke uvanlig, men slike begreper har ofte mer metaforisk enn operasjonell verdi. Eisner sier det egentlig selv - det som uttrykkes i en meningsform er ikke direkte 'oversettbar' til en annen. Halliday, selv grammatiker, skal som en åpning for det semiotiske ha sagt at Language is just one way of meaning. Resultatet av 'språkfikseringen' blir ofte det som går under den kritiske betegnelsen 'logosentrisme' (Jensen, 1995). En lar språk som meningssystem være mer eller mindre grunnleggende og premissgiver for tenkning i andre semiotiske systemer, noe som kan ende i 'lingvistisk imperialisme' eller hva poststrukturalister har prøvd å undergrave, strukturalisme.

Eisner er likevel kritisk til at begreper skulle være lingvistiske i sin natur; de bør snarere ses som sensoriske. De har sitt utspring i kropper av kjøtt og blod og gjennom erfaring blir begrepene til en slags indre ikoner. I artikkelen The Role of the Arts in Cognition and Curriculum setter han det på spissen med utsagnet: "In the beginning there was the image, not the word (Eisner, 1985, s. 204)". Form er empirisk. Han foreslår at en bør se erfaringsbehandlingen av representasjonsformene på prinsipielt tre ulike måter, nemlig mimetisk, ekspressivt og konvensjonelt. Den mimetiske formingen imiterer, gjennom et visst materiale (lydlig, visuelt etc.) overflatetrekkene til det som skal representeres. Analogi blir et viktig grep, slik som f.eks. metaforene i språk ('fjellfot').

Det ekspressive fokuserer på det som uttrykkes, og ikke på hva det måtte ligne rent overfladisk. Her bruker Eisner en kjent spissformulering av Picasso som eksempel: "A painter takes the sun and makes it into a yellow spot, an artist takes a yellow spot and makes it into the sun (Eisner, 1985, s. 207) ". Som kontrast bruker den konvensjonelle modellen eller tilnærmingen et arbitrært tegn, et tegn man sosialt er blitt enig om. Eisner understreker imidlertid at i kunst er de tre formene gjerne kombinert. Men måten disse representasjonsformene behandles på i ulike fag, er gjerne typisk for hvert enkelt fagområde. Han ser f.eks. faget matematikk som konvensjonelt i det alt vesentlige, selv om en kan påpeke estetiske trekk ved matematiske ytringer. De visuelle kunstartene derimot, tenderer mot å vektlegge det mimetiske og det ekspressive. Språk tenderer mot å behandles konvensjonelt og ekspressivt (og noen ganger mimetisk slik som i onomatepoetiske/lydmalende ord).

Eisner påpeker videre at formelementene står i forbindelse med hverandre. De har en syntaks, og dersom syntaksen er åpen, er meningene gjerne det også. Det åpnes for et subjektivt element som det sterkt konvensjonelle gjerne fortrenger, altså en figurativ versus regelstyrt syntaks. Her er vi ved et kjernepunkt for Eisner:

The importance of this distinction between rule-governed and figurative syntactical emphases becomes apparent when we consider the kinds of cognitive processes that each type of syntax elicits. Learning of rules fosters aquiscence: one learns to obey a rule or to follow it. Figurative syntaxes, by contrast, encourage invention, personal choice, exploratory activity, and judgement. The use of forms whose syntax is figurative is an uncertain enterprise, since there are no formally codified rules to guide judgements. The student, like the artist, is thrown on his or her own resources (Eisner, 1985, s. 209). 
I arbeider med vekt på 'det figurative' trener en på å vurdere, men ikke ved å anvende klare standarder, men ved å appellere til en form for rasjonalitet som fokuserer på riktigheten av en form i relasjon til en funksjon. På basis av sitt syn trekker Eisner en rekke konklusjoner mht hva dette betyr i utdanningssammenheng. Her dveler jeg ved tre.

For det første: Enhver forståelse av intelligens som unngår det å ordne kvalitative aspekter gjennom direkte erfaring neglisjerer et sentralt trekk ved hvordan et intellekt epistemologisk sett fungerer. For det andre: "The realm of meaning has many mansions (Eisner 1985:211)." Det er ikke mulig å representere eller å forstå alt i én form. En må følgelig utvikle mange former for 'literacy'. Og for det tredje kan fortrolighet med andre representasjonsformer forbedre studenters evne til å presentere mer tradisjonelle representasjonsformer:

The ability to create or understand sociology, psychology, or economics depends on the ability to perceive qualitative nuances in the social world, the ability to conceptionalize patterns from which to share what has been experienced, and the ability to write about them in a form that is compelling. Without such perceptivity, the content of writing will be shallow. Without the ability to manipulate conceptions of the world imaginatively, the work is likely to be uninspired. Without an ear for the melody, cadence, and tempo of language, the tale is likely to be unconvincing. Education in the arts cultivates sensitive perception, develops insight, fosters imagination, and places a premium on wellcrafted form (Eisner, 1985, s. 212).

For fagdidaktikere i estetiske fag vil nok min understrekning av Eisners hovedpunkter, som at form og kunnskap henger $\mathrm{i}$ hop, at det finnes ulike tegn og representasjonsformer eller at det finnes meningssystemer utenfor språket som har med kunnskap, rasjonalitet og intelligens å gjøre, være å åpne åpne dører. Mitt poeng er snarere at det har prinsipielle kunnskapsteoretiske og følgelig didaktiske og begrepsmessige konsekvenser at Eisner velger bort semiotikk. For det første opererer han med form og kunnskap som en dyade, det vil si en logisk enhet som etableres gjennom kombinasjon av to og bare to (tilstrekkelige) aspekter eller konstituenter, altså en lukket kategori, et avgrenset begrep, et håndterlig fenomen. Han får dermed ikke et godt nok grep om et tredje sentralt aspekt, nemlig handling, dvs. det savnes et bevisst eller bedre, et eksplisitt pragmatisk perspektiv. Han blir derfor avhengig av å forklare på begreps- og ikke på kommunikasjonsplanet.

For det andre etablerer han følgelig ikke noe begrep for kommunikative representasjonsformer, det vil si et makrobegrep for hvordan kulturuttrykk kan forstås eller tolkes kommunikativt. Når det gjelder representasjonsformene synes han ikke å ta opp eller nyttiggjøre seg noen av de makro-begrepene som har vært budt til torgs, slike som skript, ramme, kode, habitus, register, diskurs eller sjanger (Ongstad, 1997). Han blir derfor stående uten en mer samlende forståelse og et mer spesifikt operativt (be-)grep, f.eks. en diskurs- eller sjangerteori som kan beskrive mer overordnende konvensjonelle aspekter ved kulturell kommunikasjon, og som kan brukes som analytisk verktøy i konkret analyse av kulturelle ytringer (Bazerman et al, 2009). Ikke desto mindre har Eisner trykket på mange av de rette ømme punktene, dvs. han har rettet oppmerksomheten mot helt essensielle sider ved forholdet mellom estetikk og kunnskap, kunst og vitenskap. Det samme gjør Løvlie (1990).

\section{Pedagogikk som estetisk virksomhet?}

Løvlie hevder at dersom pedagogikk er fremstilling og formidling av samfunn og kultur, så er pedagogikk i utgangspunktet også selv en estetisk virksomhet. Hvis det er slik, kan ikke estetikerne påberope seg en spesiell estetisk innsikt og praksis som skulle adskille seg vesentlig fra f.eks. språk og naturfag. Og jo mer de sistnevnte fagene fagliggjøres og formaliseres, desto mer svekkes gjerne det estetiske perspektivet (Løvlie, 1990, s. 1-2). I følge Løvlie skiller en gjerne mellom tre ulike estetiske kunstteorier, som til dels antydes å ligge etter hverandre i tid rent historisk: den mimetiske, den 
ekspressive og den transformative teori. Klassisk teori var mimetisk idet den oppfattet kunst som håndverk. Kunst var etterligning etter et forbilde. Idé og form var fore-gitt og verket selv, dets 'vesen', ble viktig. Det ble lagt lite vekt på kunstneren eller på mottakeren. Dette er et aristotelisk syn. I Poetikken koblet Aristoteles læring og imitasjon og knyttet dermed estetikk som erfaring til oppdragelse mer generelt. Løvlie mener denne kunstforståelsen holdt seg til midt på 1700-tallet da den ble utfordret av den ekspressive forståelsen.

Den mimetiske teori hadde lite plass for det nye, det originale og grensesprengende. Dette ble sentrale elementer i den ekspressive oppfatningen som kom med romantikken. Barnet ble tilskrevet en subjektiv skaperkraft. Nå ble det det skapende vesens 'natur' som kom i fokus. Kunst kommer fra det indre, en særegen genius. Historisk fikk en en overgang fra logos til poiesis, det poetiske var nærmere menneskets natur. Rousseaus Émile målbærer det ekspressive med sin understrekning av at det ekte finnes i barnet, men kan gå tapt, forderves. Løvlie hevder at denne romantiske grunnholdningen ikke bare er historisk, men et vesentlig element, både i den radikale reformpedagogikken og i 70-årenes dialogpedagogikk (Løvlie, 1990, s. 3). Han er dypt skeptisk til 'det naturlige'. I et kapittel han kaller Dekonstruksjon av det naturlige viser han hvordan 'naturen' kan avsløres som en historisk og kulturkritisk metafor. Han oppsummerer slik:

Jeg har argumentert mot estetisk subjektivisme, mot tanken om at sentret i erfaring og oppdragelse
finnes i individets indre verden og ikke i handlingen og fullbyrdelsen. Den estetiske erfaring er
relasjonell: ingen kommer spontant til seg selv verken gjennom den kunstneriske skaping eller den
estetiske opplevelse. Individet omdanner seg i en prosess der det ikke finner tilbake til noe 'egentlig' i
seg selv, men snarere objektiviserer seg i en utsatt og risikabel verden. Her kan amerikansk
pragmatisme, slik vi møter den hos Dewey, forenes med kritisk hermeneutikk (Løvlie, 1990, s. 7).

Den transformative teori ser den estetiske erfaring som poetisk eller skapende. Det dreier seg om selvrealisering i det komplekse forhold mellom skaper, verk og mottaker. "Man kan gjerne fokusere på ett av perspektivene i dette forhold, men ingen av perspektivene alene forklarer den estetiske erfaring (Løvlie, 1990, s. 10) ". Den transformative teori bygger for det første på en hermeneutikk som knytter mening til den fortolkningsmessige helhet, for det andre til en dialektikk som kan beskrives ved 'fremmedgjøring' og for det tredje en samtale som er poetisk og som omfatter diskursen.

Avslutningsvis drøfter Løvlie hvorvidt Kant og Habermas kan sies å representere den transformative teori. Selv om de begge helt klart faller utenfor både en mimetisk og en ekspressiv teori, og begge vektlegger erfaring og handling som viktig, fungerer de likevel utilstrekkelig; Kant fordi han, når det kommer til stykket, generaliserer smaken og Habermas fordi han tvinger kravet til 'samtalen' inn i mer formal forståelse av diskursivitet. Felles for dem begge, og i opposisjon til en transformativ teori, er at de gjør den estetiske dimensjonen til en særegen og spesiell erfaring. I den transformative teori sammenholdes den moralske og teoretiske diskurs med den estetiske samtale. Den innebærer ikke noen invitasjon til irrasjonalitet (Løvlie, 1990, s. 14).

Selv om Løvlies poeng er å håndtere problemet 'den estetiske erfaring' historisk-filosofisk slik at en ser trådene mellom fortid og nåtid, er det sentrale aspekter som kanskje ikke kommer klart nok til overflaten. Slik jeg ser det står en overfor et relasjonelt problem. Teksten kunne kanskje dermed med fordel si mer eksplisitt at overgangen fra en kategoriell til en relasjonell tenkning vil innebære et paradigmeskifte rent filosofisk og logisk. Selv om det kanskje ikke er så uttalt hos Løvlie, så har flere av hans tredelinger klar semiotisk signifikans, dvs. de kan kobles med sentrale tegnteorier. Det gjelder forholdet kunster-verk-mottaker som motsvarer tradisjonelle kommunikasjonsmodellers måte å tenke på. Det gjelder forholdet mellom det mimetiske, det ekspressive og det transformative, som til en viss, men bare til en viss grad korresponderer med hovedaspektene i ytringer henholdsvis form, innhold og funksjon. Og det gjelder en oppdeling av kommunikasjon i en estetisk, teoretisk og praktisk diskurs, 
noe han henter fra Kant. Denne tredelingen synes å ha visse likhetstrekk med Bühlers tegnfunksjoner, Hallidays makro-funksjoner og Bakhtins ytrings- og sjangerteori siden disse tre direkte og indirekte kan være påvirket av Kants klassiske tredeling (Bühler, 1934; Halliday, 1978 og Bakhtin, 1986). Estetikk kan altså med full rett kreve å bli inkorporert i pedagogikk og følgelig didaktikk, på linje med epistemologi. Estetikken kan f.eks. ikke forvises til det praktisk-estetiske faghjørne eller minimaliseres til et spørsmål om form eller smak. Problemet er imidlertid at en neppe har hatt gode nok teorier eller nok relevante empiriske studier til å vise hvordan elementene faktisk kobles $\mathrm{i}$ konkrete ytringer/kontekster (Thavenius, 2002).

Så langt estetikk i relasjon til semiotisk kommunikasjon og kunnskap. Det skulle fremgå at jeg deler Eisners og Løvlies oppfatning at estetikken som domene ikke bare bør utvides, men også kobles direkte til kunnskap. I følge konstruktivister er det den lærende som bygger opp kunnskap; å se kunnskap som noe i seg selv blir uakseptabelt, og med konstruktivismen flyttes oppmerksomheten pedagogisk sett fra det som skal læres mer mot den lærende. Videre blir de emosjonene som omgir eller inngår i læringsprosessen like viktige som det rent kunnskapsmessige aspektet (Illeris, 1999). Likevel kan ikke denne koblingen bare skje rent 'bi-lateralt', som en direkte kobling mellom form og innhold. Bruk, dvs. pragmatikk må med. Men det kompliserer umiddelbart teoretiseringen, for hvordan skal syntaks, semantikk og pragmatikk i det hele tatt kunne føres sammen i én, mer helhetlig teori? En hensikt med å gå dypere inn i Eisners og Løvlies tekster har vært å forsøke å vise at selv om det triadiske prinsipp tilsynelatende kan fremstå som 'enkelt', kompliseres bildet så snart en kommer under overflaten, men en viss klargjøring er mulig.

\section{Som estetikk, så etikk}

Om en tar utgangspunkt i en triadisk, dvs. en kommunikativ semiotisk oppfatning, vil en tilnærming mellom estetikk og kunnskap ikke kunne gjøres uten at en samtidig kobler seg opp mot etikk. Mye av hva som er blitt sagt ovenfor om forholdet mellom estetikk og kunnskap gjelder imidlertid også i grove trekk for etikkens forhold til hvert av disse to aspektene. Selv om jeg ikke vil gå inn på dette feltet mer detaljert, fremsetter jeg likevel punktvis, dvs. noe fortettet og mindre begrunnet, noen konkrete påstander om etikkens koblinger til de andre feltene. I boka Aesthetics and Ethics, med den symptomatiske undertittelen Essays at the Intersection, drøftes en rekke utfordringer en kobling kan gi (Levinson, 1998) og delvis med utgangspunkt i Baumann (1995/1993) kan en, mer summarisk hevde at:

- Etikk er et perspektiv som er basert på handlingsfokusering av kommunikasjon

- Pragmatikk er beskrivelse, etikk er vurdering av handling

- Normativ pragmatikk og moral (= normativ etikk) overlapper hverandre

- Etikk kan ikke skilles fra (semiotisk) kommunikasjon

- Etikk kan derfor heller ikke vurderes adskilt fra estetikk og epistemologi

- Det er alltid et estetisk og et epistemologisk aspekt knyttet til et etisk spørsmål

- Evaluering av ytringers form gir estetikk, evaluering av deres referanse gir epistemologi og evaluering av handling gir etikk

- Verdi- og validitetsvurderinger skjer i og parallelt med ytringen, dvs. samtidig implisitt og eksplisitt, bevisst og ubevisst

- Alle tre aspektene estetikk, epistemologi og etikk må forholde seg til to nivåer - et konkret ytringseller handlingsnivå og et mer abstrakt kontekstnivå. Det betyr at 'mening' bare kan ytres og fortolkes i relasjon til begge nivåer 
Langt på vei mangler disse innsiktene. Skal de inn i fagdidaktikkene og i didaktikk på en ny og prinsipiell måte, må imidlertid fagfeltene og deres respektive didaktikker ta et oppgjør med sitt forhold til språk og semiotikk som teoretiske fenomener, enten nå dette gjøres uttalt eller uuttalt (tas for gitt). Delvis har dette allerede skjedd i mange fag (den såkalte diskursive eller språklige vending) (Ongstad, 2004b). En tradisjonell språkoppfatning, som f.eks. den som tar utgangspunkt i Saussure, kan i prinsippet sies å være dyadisk. Den baserer seg på et tilstrekkelig entydig tegn, satt sammen av betegner (form) og betegnet (innhold) (Saussure, 1916,1983). En slik tegnforståelse er selvsagt ikke gal, men i en rekke faglige og didaktiske kontekster blir den utilstrekkelig. Perspektivet må derfor utvides, fra dyadisk fokus på form og innhold til et triadisk fokus som også inkluderer handling, dvs. fra å være grammatisk og setningsbasert til å være pragmatisk ytringsorientert, fra vekt på språk til vekt på språk og semiotikk. Mange fag- og vitenskapsdisipliner synes imidlertid å vegre seg mot å skulle skjerpe fagligheten gjennom mer inngående studier av egne fags semiotikk og nøyer seg med et mer tradisjonelt, og gjerne innforstått språksyn (Ongstad, 2012a og 2006).

\section{Forholdet lingvistikk - semiotikk}

Når det gjelder semiotikk har Saussure egentlig hatt en paradoksal innflytelse. Saussure kan ses som grunnleggeren av moderne språkteori, av lingvistikken (Saussure, 1916 og 1983). I hans fotspor er det etablert et paradigme som har festet sitt grep, ikke bare på oppfatningen av språk som 'isolert størrelse', men også på tegnforståelse innen vitenskap mer generelt. Det kan derfor være grunn til, i et lengre sitat, å minne om hva Saussure selv uttrykte like etter forrige århundreskifte:

A language $[. .$.$] is a social institution. But it is in various respects distinct from political, juridical and$ other institutions. Its special nature emerges when we bring into consideration a different order of facts.

A language is a system of signs expressing ideas, and hence comparable to writing, the deaf-and dumb alphabet, symbolic rites, forms of politeness, military signals, and so on. It is simply the most important of such systems.

It is therefore possible to conceive a science which studies the role of signs as part of social life. It would form part of social psychology, and hence of general psychology. We shall call it semiology (from the Greek semeion, "sign"). It would investigate the nature of signs and the laws governing them. Since it does not yet exist, one cannot say for certain that it will exist. But it has the right to exist, a place ready for it in advance. Linguistics is only one branch of this general science. The laws which semiology will discover will be the laws applicable in linguistics, and linguistics will thus be assigned to a clearly defined place in the field of human knowledge (Saussure, 1983, s. 15-16).

Saussures eget lingvistiske program og effekten av det kom paradoksalt nok til å fortrenge eller utsette den bebudede fremveksten av en systematisk 'semiologi' (som Saussure kalte det ufødte barnet) eller semiotikk (som en omsider er blitt enig om å kalle babyen). Slik sett ble han sin egen tankes gjøkunge.

Selv om semiologi egentlig allerede hadde hatt en semiotisk forløper i Peirce (1940/1965 og 1994) og selv om det innenfor lingvistikken har vært tungvektere som har åpnet for en mulig generell semiotikk, som Roman Jakobson og Louis Hjelmslev, var det først mot slutten av 1960-tallet at en mer systematisk semiotikk så dagens lys. Den såkalte tekstsemiotikken gjorde opprør mot strukturalismen, og kanskje særlig den strukturalismen som lå i lingvistikken. Skoler og retninger som den russiske formalismen, Prager-skolen og Sovjet-semiotikerne inspirerte til kritikk av det herskende paradigme, og sammen med en rekke franske teoretikere som Barthes, Kristeva, Greimas, Derrida og Todorov, men også Eco, bidro kritikken til etablering av det en kan kalle tekst-semiotikk (Eco, 1976; Barthes, 1977; Nöth, 1990). 'Språk' var imidlertid fortsatt et dominerende fokus.

Også disse tilnærmingene har imidlertid vært utsatt for kritikk og konkurranse fra flere hold. Flere teoretikere ønsket f.eks. å knytte sterkere bånd mellom språket og den sosiale dimensjonen (Ongstad, 
2007). Det har vokst frem et felt som en kan kalle sosial semiotikk. Halliday, som med sin Language as Social Semiotics (1978) la grunnen til en retning som særlig har vært særlig sterk i Australia, men som også har tilhengere i bl.a. England, Nord-Amerika og Norge, som f.eks. Berge o. a. (1998).

En annen er Bakhtin, russeren som ble 'oppdaget' ganske sent i Vest. Bakhtin tok allerede tidlig på 20 -tallet et oppgjør med Saussures dikotomiske paradigme. Han ville oppheve det absolutte skille mellom diakroni og synkroni, mellom la langue og la parole. Bakhtins utgangspunkt er den faktiske ytringen, ikke det teoretiske systemet (Ongstad, 2004c). Bakhtin har etter at hans skrifter er blitt oversatt til engelsk og fransk i løpet av kort tid fått stor innflytelse på tenkning om språk og kommunikasjon på felter som litteraturteori (Kristeva), nyere retorikk og semiotikk (Threadgold), film- og medieteori (Hodge og Kress, Todorov), sosiologi (Gardiner) og utdanning/didaktikk (Lemke). Flere av hans sentrale begreper som ytring, sjanger, aksent, ideologi, karneval, orkestrering og dialog har inspirert en lang rekke teoretikere i ulike land og på ulike fagområder (Bostad, 2004).

Felles for sosial-semiotikk i ulike tapninger er altså understrekningen av tegnets sosiale funksjon. Mens Halliday vektlegger linjen fra (grammatisk) struktur til sosial handling, er Bakhtin mer opptatt av tegnets eller rettere ytringens flertydighet. Årsakene til flertydigheten ligger dels i tegnets sosiale natur (det har i seg selv ingen kjerne, ingen absolutt mening) og dels i tegnets ubevisste ideologiske funksjon vis-à-vis brukeren.

\section{Fram mot en utdanningssemiotikk?}

I mer programmatiske artikler ble det for noen årtier tilbake forsøkt etablert generelle forskningsstrategier og definerte behov med utgangspunkt i semiotikk. (Se f.eks. Bense, 1977; Imbert, 1980; Cunningham, 1987 og Nöth, 1990.) Hva en kunne kalle utdannings- eller undervisningssemiotikk vil undersøke undervisning og læring som en generell tegn- og kommunikasjonsprosess. Bense (1977) argumenterer for at semiotikk er grunnleggende for pedagogikk fordi den utvikler kognitive evner på alle persepsjonsnivå og tilbyr en generell kommunikasjonsteori, en teori som er nødvendig for undervisningens didaktikk.

Flere har pekt på at semiotikk synes fundamental for undervisning siden den utvikler teorier om mening i videste forstand idet det tilbys et perspektiv som utvider interessen fra det verbale til også å inkorporere det non-verbale. Cunningham (1987) hevder at utdanning som baserer seg på semiotisk innsikt vil måtte endre vår pedagogiske tenkning. Hva en kan se er konturene av er en tverrfaglig, semiotisk og didaktisk utdanningsvitenskap:

Knowledge would be regarded as a process, not a static structure to be learned and remembered. The curriculum would emphasize ways of knowing not simply in the traditional verbal and mathematical modes, but in a variety of interconnected modes. Traditional subject matter boundaries would dissolve as it became clear that the ways of knowing in the humanities are not fundamentally different from the ways of knowing in the physical and social sciences. Students would not be taught what to think but how to think (Cunningham, 1987, s. 214).

Imbert (1980) hevder at semiotikk er viktig for å forstå Sapir-Whorf-hypotesen i full bredde. Det er tegnsystemene (som semiotikken unders $ø$ ker) som befordrer de verdensbilder vi ubevisst er bærere av. Pedagogikken og semiotikken har en viktig oppgave i forhold til slike skjulte verdensbilder:

From an ideal semiotic point of view, a true and complete methodology of pedagogy should lead to a program that would allow, at the same time, both the freedom of a being mastering (consciously or unconsciously) the rules of the manifold systems giving him the possibility to communicate, and also the freedom of the being who would be able to break the rules and to "see" beyond the systems (Imbert, 1980, s. 280). 
Et semiotisk perspektiv på relasjonen estetikk - epistemologi - etikk er altså viktig for fag-/didaktikk, ikke minst fordi den kunnskapen vi omgir oss med i større grad enn før synes å være preget av mer usikkerhet, tvil og skepsis, en utvikling fagdidaktikkene må forholde seg til. Konkret gjelder det f.eks.:

- forståelse av det semiotiske tegnet, det grunnleggende 'mikro-element' i all kunnskap, kommunikasjon og læring

- synet på sjangrene og diskursene, makro-størrelser som organiserer kommunikasjon og kunnskap og som gir uttrykks- og fortolkningspotensial til den enkelte og samfunnet,

- formidling og oppbygging av fagkunnskap gjennom institusjoner som med distanse til 'virkeligheten' er særlig tekst- og tegnavhengige

- motsetning mellom på den ene siden det trygge laerte og på den annen side det utrygge, det ennå ulcerte, det gitte ('tema') og det nye ('rema'), og ikke minst ...

- de paradigmatisk ulike og ofte inkompatible metarefleksjonene over disse forhold

På disse og flere andre pedagogisk relevante områder gis det få helt sikre steder å ytre seg fra, enn si, å lære fra. Baumann (1995/1993) har pekt på at en utvikling for selvets, samfunnets og verdenens enhet og helhet synes å løse seg opp i truede og truende fragmenter. Dermed provoseres selve grunnlaget for meningssøkende og meningsbyggende læring og selvforvaltning. Et slikt mosaikkpreget bakgrunnsteppe utfordrer derfor didaktikkene til å finne tilnærminger som kan fungere som tilstrekkelig meningsfulle til å håndtere meningsfragmentering, ikke bare for den enkelte, men også som redskap til å kommunisere med andre - i seg selv egentlig et paradoks (Habermas, 1988). Mens Habermas tar opp kampen mot tendensene synes Baumann å ta en slik utvikling for gitt.

Jeg vil avrunde denne delen med et forsøk på en 'normativ', men likevel empiribasert konklusjon om ønskede egenskaper ved en generell psykologisk-sosiologisk-semiotisk modell for analyse av kulturelle enheter som kan være didaktisk relevant på tvers av fag (Ongstad, 1997). Eller for å si det på en alternativ måte: Nedenfor har jeg satt opp noen krav en kan stille til teorier, modeller eller tilnærmingsmåter som har ambisjoner om å kombinere nivåene mikro og makro. Sagt på en tredje måte: Teorier eller fag og fagdidaktikker som er avhengige av å forstå dynamikken mellom begreper som 'selv', 'verden' og 'samfunn', bør legge en semiotisk, det vil si en kulturrelatert referanseramme til grunn som:

- er prosessuell,

- forklarer nyproduksjon og reproduksjon av kulturelle former,

- forklarer spesifikt dynamikken mellom mikro- og makronivået,

- er semiotisk triadisk slik at struktur-, referanse- og handlingsaspektene og deres innbyrdes dynamikk tas i betraktning,

- relaterer den konkrete mikro-enheten og den immanente makro-enheten til (hele) kroppen (og ikke bare hjernen/verbal-språket),

- forklarer hvordan og hvorfor makroenheten også arbeider ubevisst (men likevel kan tenkes på og bearbeides),

- godtgjør at spesifikke aspekter ved makrobegreper er relatert til andre makrostørrelser i et relasjonistisk, delvis systemisk, delvis tilfeldig nettverk av aspekter, og som (derfor) er eksplisitt semiotisk i sin forståelse (Ongstad, 1997).

\section{Semiotikk som kunnskaps- og vitenskapsteori - fra dyader til triadiske paradokser}

Som nevnt i innledningen har flere psykologer, samfunnsvitere, semiotikere og tekstteoretikere pekt på det påfallende triadiske aspektet ved ulike former for kommunikasjon. Disse har, i større eller mindre 
grad, utviklet teorier basert på triadisk, dvs. semiotisk og/eller kommunikativ tenkning, som Peirce (1940/1965 og 1994), Morris (1938/1970), Bühler (1934), Ben-Amos (1969), Halliday (1978 og 1994), Martin (1997), Miller (1984), Habermas (1988), Bakhtin (1986), Jensen (1994), Baumann (1995/1993) og Hernadi (1995). Det bør kanskje umiddelbart presiseres at det ikke hefter noen mystikk ved det triadiske. Det er det minste antall integrerte og gjensidig definerte hovedkonstituenter som er nødvendig for å etablere en kommunikativ ytring (substans/form, referensielt innhold og adressiv funksjon).

Som en introduksjon til en varsom sammenfatning av slik tenkning vil jeg sitere fra Baumanns bok om postmoderne etikk der han får frem poenger som er helt sentrale for håndtering av slike triader (Baumann, 1995/1993). Særlig advarer han mot å behandle aspektene som kategorier. Dessuten understreker han at en må se prosesser både som sammenvevde og som delvis adskilt:

(...) Det sociala rummet självt är dock inte alls något enkelt begrepp utan behöver redas ut ytterligare. Framför allt bör det betraktas som ett komplicerat samspel mellan tre sammanvävda, men ändå skilda processer - den kognitiva, den estetiska och den moraliska "rumsbildningen" - och deras produkter. Man talar ofta om de tre varianterna av "icke-objektivt" och "människoskapat" socialt rum i ett andetag och använder de tre begreppen som om de stod för "aspekter" av samma sociala kartläggning. Men även om alle tre rummen utnyttjar föreställningar om närhet och avstand, slutenhet och öppenhet, skiljer sig de tre rumsbildande mekanismerna i sin pragmatik och i sina resultat. Om det kognitiva rummet konstrueras intellektuellt, genom förvärv och fördelning av kunskap, tecknas det estetiska rummet känslomessigt, genom den uppmärksamhet som styrs av nyfikenhet och sökandet efter erfarenhetsmässig intensitet, medan det moraliska rummet "konstrueras" genom en ojämn fördelning av det upplevda/åtagna ansvaret (Baumann, 1995/1993, s. 182-183).

Ofte lar en heller fremstillinger skje mer poengtert gjennom dikotomier, forskning settes opp mot undervisning, individualisering mot institusjonalisering, kunnskap mot vare, modernisme mot postmodernisme, essensialisme mot konstruktivisme, teori mot praksis osv. Imidlertid bør en nå spørre om det ikke både er ønskelig og mulig å komme bort fra en rekke fastlåste og til dels ufruktbare motsetninger (Ongstad, 2004).

Semiotikk er altså en vitenskap eller et fagområde som ser kultur og natur som tegn (Nöth, 1990). Semiotikk er dermed videre enn, men inkorporerer samtidig 'språk' i betydningen verbalspråk og kan derfor anvendes på de fleste kultur- og kunnskapsområder. Ytringer i fag og profesjoner på ulike nivåer, enten ytringene uttrykkes gjennom faglige symboler eller aktivitet, kan følgelig ses som kommunikative kultur- og/eller natur-tegn. Forenklet kan en regne med to kommunikasjonsnivåer - et konkret ytringsnivå hvor en forholder seg til sansbare tegn, tekster, ytringer, praksiser og et abstrakt kontekstnivå, hvor en anvender internaliserte kommunikasjonsformer, som sjangre og diskurser, nærmest som 'medbrakte', dels situasjonsgivende kontekster. Kontekstnivået uttrykkes altså ikke nødvendigvis direkte, men inngår gjerne som potensial for å danne mening i samfunn, kulturer og fag (Martin, 1997; Ongstad, 1997).

Når en mentalt og analytisk gjennom språket fokuserer på ytringsnivået, dvs. på selve ytringen, blir konteksten bakgrunn, en mekanisme som gjerne blir karakterisert med metaforparet figur-grunn (Ongstad, 2002b). Sjangrene, diskursene eller kontekstene er imidlertid alltid dynamiske ved at de leverer fortløpende tidligere 'lagret' mening både til den som ytrer og den som mottar eller fortolker (Halliday, 1994). Dette nivået eller denne kombinerte produksjons- og fortolkingsmekanismen fungerer derfor som 'tema' i ytringer, altså det som det generelt ytres noe om (Martin, 1997; Ongstad, 2007). Alle språksamfunn og kulturer har utviklet og utvikler stadig mer overordnede kommunikasjonssjangre eller diskurser som hjelper en med en generell tematisering, slik som 'dødsannonse', doktoravhandling, salmesang, joik, fruktbarhetsdans, grafitti osv. Når en ytrer, kombineres alltid det gitte/kjente, og som en altså forenklet kan kalle 'tema' og stadig nye, ukjente 
element, som innen tekstteorier i dag gjerne kalles 'rema' (Halliday, 1994; Ongstad, 2004a). De ulike tegnene i ytringen (eller teksten) får derfor alltid tilført ny mening, bl.a. fordi situasjonen i prinsippet alltid er ny.

Om vi går tilbake til de 7 strekpunktene i forrige underkapittel, vil en se at langt på vei blir disse dekket av den formen for sosio-semiotikk som bygger på Hallidays funksjonelle grammatikk. I Ongstad (1997 og 2006b) finnes mer inngående drøftinger av de ulike 'kravene' og som fører frem til et teoretisk rammeverk, kalt posisjoneringsteori (1999, 2007a og 2007b). En delvis selvkritisk fremstilling med vekt på problemet validitet finnes i Ongstad (2012b).

Vekslinger mellom gitt og nytt (tema og rema) eller dynamikk i tegnets betydning ses som en grunnleggende semiotisk prosess, gjerne kalt 'semiose', et begrep som noe forenklet kan defineres som betydningsendring (Ongstad, 2004). All kunnskaping og læring, i undervisning så vel som i forskning kan derfor ses som semiose, som betydningsendring, eller endring i den lærendes menings- og begrepsstrukturer, dvs. som kunnskapsendring. Semiosen utgjør altså ikke bare kunnskapens brennpunkt. Semiosen blir det nye aspektet i kunnskapen, men inngår samtidig i et semiotisk, det vil si kommunikativt personlig og felles system som den enkelte allerede har tatt og vil ta del i. Semiotikken tilbyr derfor en langt mer grunnleggende kommunikativ måte å forstå læring og kunnskapsutvikling på enn den en gjerne finner innen mer rent språklig basert teorier og tilnærminger. En sentral utfordring er imidlertid at politikere, forskere, pedagoger og lærerutdannere ofte implisitt baserer seg på en mer ensidig språklig (det jeg ovenfor kalte en logosentrisk) forestilling, og derfor indirekte bidrar til å opprettholde et mindre fruktbart status quo.

Videre kan alle ytringer altså sies å ha et form-, innholds- og bruksaspekt. Noen få teoretikere anser at samme tredelingen også gjelder kontekstnivået, enten en nå betegner dette som diskurs, kontekst eller sjanger (Halliday, 1994; Martin, 1997; Fairclough, 1992; Ongstad, 2004). Ytringer og deres meningspotensiale (jeg foretrekker selv å bruke begrepet sjanger, av fr. 'genre' for dette) står i et dynamisk forhold til hverandre; dynamikk mellom struktur, referanse og handling på begge nivåer og gjennom vekslinger mellom gitt og nytt (tema og rema). A se ytringer og sjangre som alltid sammensatt av tre hovedaspekter får, som jeg vil vise i neste underkapittel en rekke prinsipielle og paradoksale konsekvenser.

\section{Oversikt over estetikk, epistemologi og etikk og/som kommunikative triader}

Det må understrekes at noen viktige forutsetninger ikke er lagt inn i oversikten nedenfor. For det første at sammenstillingen skal forstås slik at alle termer skal betraktes, ikke som egne kategorier, men som aspekter, og at de derfor i prinsippet anses å stå i forbindelse med hverandre i et relasjonelt system. For det andre er det en forutsetning at det i tillegg trengs et kommunikativt, immanent makronivå over det ytringsnivået som de aller fleste begrepene i oversikten tenkes å inngå i (Ongstad, 2004, s. 103). For det tredje 'mangler' to aspekter som også må inngå i systemet, nemlig aspektene eller dimensjonene tid og sted. Form, innhold, bruk, tid og sted utgjør sammen en forent pentagon hvor alle fem aspektene forutsetter hverandre gjensidig og opptrer samtidig i konkrete ytrings- og tolkningsøyeblikk (Ongstad, 2012a). Prosesser eller aktiviteter knyttet til de respektive aspektene kan følgelig karakteriseres gjennom de fem verbene å uttrykke, å vite, å handle, å tidfeste og å stedfeste.

Noe tilsvarende gjelder da henholdsvis estetikk, epistemologi, etikk, kronologi og topologi (Ongstad, 2012b). Rammeverket skal altså ses som systemisk snarere enn som et (fast) system fordi det er dynamisk og fordi 'alt-henger-sammen-med alt'. Dette betyr ikke at rammeverket pretenderer å 
forklare alt, men snarere motsatt at kompleksiteten understrekes og åpnes for problematisering (jf. diskusjonen av Eisner og Løvlie ovenfor). Sist, men ikke minst: aspektene som gjengis her er overordnede hovedaspekter, og under hvert av disse vil det ved konkrete analyser av tekster og kulturelle ytringer åpne seg et vell av underbegreper og fenomener på ulike nivåer. Halliday bruker begrepet delicacy, eller kanskje kunne en på norsk si fingraderthet, om studier på detaljnivå (Halliday, 1994; Ongstad, 2012b).

Det kan ikke understrekes sterkt nok at rammeverket $i k k e$ selv gir noen egen analysemetode som en kan operasjonalisere direkte fra. Men flere kjente teoretikere har på basis av ulike triadiske tenkemåter utviklet mer eller mindre spesifikke metodologiske tilnærminger som i prinsippet skulle kunne ses i forhold til rammeverket. Mest brukt og kjent er kanskje Hallidays arbeider, og systemisk funksjonell grammatikk (SFG) og sjangeranalyser som er tilnærminger basert på hans arbeider. I Norge blir metodene ofte brukt i studier av (sammensatte) tekster, men blir også brukt i kritisk diskursanalyse inspirert f.eks. av Fairclough (1992). Videre har Habermas' kommunikasjonsteori, Searles talehandlingsteori og Bakhtins sjangerteori vært anvendt $i$ analyser med triadisk tilsnitt. Innen filmteori hevdet Altman (1984) at film burde analyseres ut fra dyaden syntaks/semantikk. Senere slo han imidlertid kontra og argumenterte sterkt selvkritisk for at film måtte studeres ut fra den langt bredere triadiske metodologien syntaks/semantikk/pragmatikk (Altman, 1999). Konkrete studier innen utdanningsforskning basert på såkalt posisjoneringsanalyse kombinert med et triadisk perspektiv finnes f.eks. hos Smidt (2007 og 2008), Ongstad (2005, 2007a og 2007b) og Braathe (2010 og 2012). En gjennomgang av styrke og svakheter ved (dobbel triadisk) posisjoneringsanalyse finnes bl.a. i Ongstad (1999).

Det finnes ellers en rekke utdanningsforskere, pedagoger og didaktikere som har anlagt en eksplisitt triadisk tenkemåte eller perspektiv, men som i liten grad har satt tredelingen i sammenheng med en eksplisitt triadisk forståelse av tegn, ytring og kommunikasjon som f.eks. Hertzberg (1898), Steiner (1927), Harré (1980, 1984 og 1991), Klafki (1985 og 2001), Gardner (1997), Hiim og Hippe (1998), Rørvik (1998), Hansen (2000) og Illeris (2000). Kanskje særlig hos psykologen Harré og pedagogene Rørvik og Illeris kan en imidlertid finne en mer differensiert forståelse av bestemte fagfelt, og som derfor kan være fruktbare utgangspunkt for mer fingraderte analyser innen rammeverket. På det estetiske området synes eksplisitt triadiske tilnærminger noe mindre utbredt, men Gardner har i sine senere skrifter lagt eksplisitt vekt på betydningen av estetikk (det skjønne) (Gardner, 1997). En gjennomført triadisk analyse på mikro-nivå, på mange måter slående lik min egen vinkling på ytringer, finnes i Kattenbelts artikkel The triad of emotion, action and reflection. A signpragmatic approach to aesthetic communication (Kattenbelt, 1994). En delvis parallell, triadisk tankegang rundt diskurs (ikke makro-begrepet) utviklet for litteratur og kulturfeltet finnes i Cultural Transactions. Nature, Self, Society (Hernadi, 1995).

Oversikten etablerer en rekke slike prinsipielle sammenhenger. Hensikten er for det første å bevisstgjøre hvor det kan oppstå 'falske' tosidige 'språklige' motsetninger, som altså heller bør føres sammen i tre, dvs. kommunikative aspekter, for det andre å vise på hvilken måte et kommunikativt hovedaspekt er koblet til den 'semiotiske' triaden og for det tredje å gi en enkel kunnskaps- og vitenskapsteoretisk referanseramme for forskning, utdanning og undervisning. Et siste, men sentralt poeng, er også å få klarere frem hvilke underbegreper til perspektivet 'estetikk' som korrelerer med de tilsvarende under epistemologi og etikk.

Rekkene og kolonnene nedenfor bør ses som sider eller aspekter i et tredimensjonalt tetraeder eller pyramide slik at alle dimensjoner er til stede og kan relatere seg gjensidig til hverandre på én gang. (Se Ongstad, 2004b.) Men ved å bruke språket som tenke- og analyseredskap, følger det gjerne en 
rasjonalistisk hang til bare å 'se' ett aspekt eller to hovedaspekt, men altså ikke tre på én og samme gang - det paradoksale ved sammenføring av språk, semiotikk og kommunikasjon, eller the blindness of focusing.

\section{Estetikk, epistemologi og etikk og/som kommunikative triader}

\begin{tabular}{|c|c|c|c|}
\hline & ESTETIKK & EPISTEMOLOGI & ETIKK \\
\hline Teoretiker/tradisjon & Form & Innhold & Bruk \\
\hline Gresk retorisk tradisjon & patos & $\log 0 s$ & etos \\
\hline Pestalozzis metaforer & hjerte & hode & hand \\
\hline Klassiske undervisningsmål & det skjønne & det sanne & det gode \\
\hline Bühler (1934) tegnaspekt & expression & representation & appeal \\
\hline tegnaspekt (ty. term) & (Ausdruck) & (Darstellung) & (Appell) \\
\hline tegnet tolket som & symptom & symbol & signal \\
\hline Ben-Amos (1969) ytringsaspekt & prosodic & thematic & behavioral \\
\hline funksjon & expressive & cognitive & functional \\
\hline Halliday (1978) tekst-aspekt & textual & ideational & interpersonal \\
\hline register-aspekt (kontekst) & mode & field & tenor \\
\hline Bakhtin (1986) & expressivity & referentiality & addressivity \\
\hline Miller (1984) & form & substance & action \\
\hline Fairclough (1992) & identity & ideational & interpersonal \\
\hline \multicolumn{4}{|c|}{ Habermas' begreper (1988:137/147; oversettelse SO) } \\
\hline Kommunikasjonsmodus & ekspressivt & kognitivt & interaktivt \\
\hline Talehandlingstype & (representativ) & konstativ & regulativ \\
\hline Tema & talerintensjon & proposisjonelt innhold & interpersonell relasjon \\
\hline Realitetsområde & indre natur & ytre natur & samfunn \\
\hline Kroppskontekst (SO's term) & selv & verden & samfunn \\
\hline Realit.relasj.'s fremtredelsesform & subjektivitet & objektivitet & normativitet \\
\hline Implisitte krav på validitet & sannferdighet & sannhet & riktighet/brukbarhet \\
\hline $\begin{array}{l}\text { Talehandlingens allmenne } \\
\text { funksjoner }\end{array}$ & $\begin{array}{l}\text { uttrykke subjektive } \\
\text { opplevelser }\end{array}$ & $\begin{array}{l}\text { fremstilling av } \\
\text { saksforhold }\end{array}$ & $\begin{array}{l}\text { etablering av inter- } \\
\text { personelle relasjoner }\end{array}$ \\
\hline Hovedaspekter ved ytring & Form & Innhold & Bruk \\
\hline Parallelle ytre prosesser & uttrykking & referering & adressering \\
\hline Kroppslige prosesser & opplevelse & forståelse & aktivitet \\
\hline Kroppslige pros.kategorier & følelse & kunnskap & handling \\
\hline Adjektiviske former 1 & emosjonell & kognitiv & sosial \\
\hline Adjektiviske former & ekspressiv & referensiell & adressiv \\
\hline Adjektiviske former & eksistensiell & informativ & appellativ \\
\hline Didaktisk/kommunikativt & Ytrer & Referanse & Fortolker \\
\hline Tradisjonelle begreper & avsender & budskap & mottaker \\
\hline Didaktiske kategorier & lærer & innhold & elev \\
\hline Forskningskommunikasjon & forsker & resultat & mottaker \\
\hline Aspektet posisjonert som & Strukturering & Referering & Adressering \\
\hline Kroppstilstand & væren & tenken & gjøren \\
\hline Kroppslig prosess & eksistering & tenking & gjøring \\
\hline Fysisk relatert til & kropp & objekt & andre \\
\hline Relatert til pronomen & jeg & det & $\mathrm{du}$ \\
\hline Effekt i/av tegnprosessen & impuls & kategori & prosess \\
\hline Mottakerens posisj. sett som & symptom & symbol & signal \\
\hline Grammatikalsk metaforisert som & adjektiv & substantiv & verb \\
\hline Grammatikalsk metaforisert som & nåtid & fortid & fremtid \\
\hline $\begin{array}{l}\text { Fagfelt } \\
\text { Språkdisipliner/semiotiske felt } \\
\text { Eksempler på prototypiske fag }\end{array}$ & $\begin{array}{l}\text { Struktur } \\
\text { syntaks } \\
\text { psykologi }\end{array}$ & $\begin{array}{l}\text { Referanse } \\
\text { semantikk } \\
\text { fysikk }\end{array}$ & $\begin{array}{l}\text { Handling } \\
\text { pragmatikk } \\
\text { sosiologi }\end{array}$ \\
\hline
\end{tabular}




$\begin{array}{llll}\text { Ped./filosofiske hovedområder } & \text { estetikk } & \text { epistemologi } & \text { etikk } \\ \text { Overdreven vekt på enkeltaspekt } & \text { subjektivisme } & \text { objektivisme } & \text { aktivisme } \\ \text { Overdreven vekt på enkeltaspekt } & \text { ekspressivisme } & \text { positivisme } & \text { funksjonalisme } \\ \text { Overdreven vekt på enkeltaspekt } & \text { formalisme } & \text { essensialisme } & \text { pragmatisme }\end{array}$

Hvis det altså legges som premiss at estetikk forstått kommunikativt kan ta utgangspunkt i form og at en grupperer de aspektene som på ulike måter kan knyttes til form (i oversikten ordnet vertikalt), så vil det fremtre en rekke nøkkelbegreper som f.eks. kan inngå i et fag-/didaktisk rammeverk. Hvert av disse enkeltbegrepene inngår samtidig i en kommunikativ og/eller didaktisk triade (ordnet horisontalt). I det følgende forfølges det gitte premisset i kombinasjon med de to tenkemåtene, med start i estetikkkolonnen.

Når en retoriker bestreber seg på å få fram en viss patos er det primært formen det arbeides med. Trekkes en historisk rask tråd fra retorikk til Pestalozzis didaktikk kan en si at patos skal tale til hjertet, til opplevelsen og i den klassiske tradisjon fremheve det skjønne som et læringsmål. Bühler var en av de første som forsøkte å teoretisere tegnet som en triadisk, udelelig helhet. Formens funksjon for Bühler var Ausdruck, expression eller uttrykk om en vil. En rekke teoretikere har etterhvert samlet seg om termene ekspressiv/ekspressivitet. Her oppstår det imidlertid et problem, sikter slike begreper til ytringen eller ytreren? Halliday, som fokuserer på språk bruker bare textual (teksten som form eller struktur), men f.eks. Fairclough og Habermas, som begge har sosiologiske interesser, taler om (hhv.) identitet og selv (som altså uttrykkes eller uttrykker seg). Fra dimensjonen form kan en altså utlede minst tre sentrale underaspekter, det emosjonelle, det ekspressive og det eksistensielle. Filosofi, estetikk og psykologi er fagfelt som studerer disse relasjonene. Men aspektene må fortolkes fordi aspektet fungerer symptomalt, formen representerer noe annet enn seg selv.

Form kan isolert sett selvsagt også ha en 'objektiv' eller substansiell side, og kan da studeres som f.eks. design, syntaks eller som ren fysisk materie, og i det siste tilfellet da selvsagt ikke qua kommunikasjon. Kanskje kan en til slutt ta med at kritikere har en tendens til å bruke begreper som subjektivisme, ekspressivisme, formalisme o.l. for å understreke at visse retninger, skoler og analyser overdriver ett bestemt aspekts betydning eller forrang.

Jeg vender nå tilbake til form/patos øverst til venstre i oversikten for å se hvordan de enkelte underaspektene for formrelaterte aspekter inngår i ulike kommunikative triader innen det epistemologiske og det etiske området (horisontalt i oversikten). Patos må (bl.a.) ses i forhold til den konkrete logos og den konkrete etos som legges inn i eller finnes i det konkrete budskapet eller fremlegget. Med andre ord må en i konkrete studier og analyser se hvordan spesifikk form avpasses etter spesifikt innhold og funksjon, og vice versa. Men det som styrer en slik avveining er nettopp den valgte kommunikasjonsformen på makro-nivå, f.eks. de konkrete sjangrene og/eller diskursene, et perspektiv som ikke er lagt inn i denne oversikten. Uten å gå for mye i detalj får en nå behov for å utvikle begreper for $h v a$ det egentlig er en studerer. På den (språk-)filosofiske siden er det kanskje særlig Habermas som har gått nærmere inn på, benevnt og 'ordnet' en rekke av disse hovedaspektene (se spalten helt til venstre i oversikten over hans meta-begreper). Han refererer ellers eksplitt bl.a. til Kants kritikker, Bühlers tegnforståelse og Searles talehandlingsteori. Særlig relevant er innbyrdes relasjoner mellom kommunikasjonsmodi, talehandlingstyper, talehandlingsfunksjoner og validitetskriterier (Habermas, 1988).

På språksiden er det altså særlig Halliday (1994) som med sin kontekstorienterte grammatikk har lagt grunnen for SFG, og som er konsekvent triadisk på minst to plan (tekst- og kontekstnivået). Som nevnt er Halliday i rollen som grammatiker i liten grad interessert i personen, i selvet. For fagdidaktikk 
som måtte anvende SFG blir det derfor viktig å klargjøre hvilken rolle kropp spiller, særlig i forhold til analysert tekst (ytringer). Tekst er kanskje mer et umiddelbart forskbart objekt enn kropp. Videre er en av de mer frekvente triadene i nyere norsk læreplanretorikk følelse-kunnskap-handling (som igjen er nært i slekt historisk både med den klassiske triaden det skjønne-det sanne-det rette og altså med den gamle didaktiske metaforen hjerte-hode-hand). Her oppstår det imidlertid ofte et forskningsmessig dilemma. For fag-/didaktikk er helheter som kropp, person og selv viktig, mens forskning vil måtte bestrebe seg mer på å finne delaspekter som passer til gyldighetsforventningene 'objektivitet' og 'intersubjektivitet' snarere enn 'subjektivitet' for nå bruke Habermas' termer. For utdanning og utdanningsforskning er dette dilemmaet sannsynligvis umulig å komme bort fra. Derfor må forskere og lærerutdannere stadig avveie validitet i forskningsarbeidet mot relevans for praksis (Ongstad, $2012 b$ og 2013 a).

Hva med kritikk og mottanker? I boka Uncertainty and Communication gjør forfatteren en grunnleggende kritisk gjennomgang av teoretikere som tar til orde for eller som legges til grunn for et mer system-preget syn på semiotikk og kommunikasjon (Grant, 2007). Det gjelder særlig Husserl, Bühler, Habermas og Luhmann, samt til en viss grad bestemte versjoner av Bakhtins såkalte dialogisme. Dette er ikke stedet for en full gjennomgang av Grants kritikk. I egne arbeider har jeg forøvrig ikke gått inn på Husserl og Luhmann, men de andre tre har jeg brukt flittig, også i denne fremstillingen. Siden Grant målbærer skepsis som også finnes blant andre kritikere vil jeg selv avslutningsvis omtale følgende forhold. Verken Bühler eller Habermas opererer egentlig med noen diskurs- eller sjangerteori, selv om makro-nivået på sett og vis finnes i Habermas' livsverdensbegrep (Ongstad, 2009). Det innebærer bl.a. at sjangrene, som kan ses som hovedmekanisme for veksling mellom fasthet og fleksibilitet, og som bestemmer grad av sikkerhet i ytringssystemene ikke er tatt i betraktning. Habermas' teori fremstår i liten grad som systemisk, ved at tenkningen begrenser muligheten til å se endringer av 'systemet' over tid. Denne grunnforståelsen finnes delvis hos Halliday ved at språket selv ses som systemisk, mens grammatikk, naturlig nok, har mer preg av stabilitet over tid. Grant har imidlertid ingen referanser til Halliday eller SFG. I Ongstad (1997) gjøres det en svært omfattende og ganske kritisk gjennomgang av hvilke konsekvenser ulike kommunikative makrobegrep kan ha for meningsdanning i kommunikative ytringer.

\section{Fordeler og ulemper punktvis som foreløpige konklusjoner?}

Kunstverk, kunstgjenstander, kunstuttrykk og artefakter er med andre ord ytringer og må, hvis de gis eller antas å ha mening, studeres og fortolkes i et triadisk eller i et femsidig perspektiv om en tar med tid og sted. Anvender en et triadisk perspektiv, betraktes 'resten' som situasjon, tid og sted (kronotop), rom, omgivelse, miljø, kultur, m.a.o. kontekst. En konfronteres imidlertid med en rekke grunnleggende utfordringer:

- Hvis kontekst ikke bare ses som en 'boks' som ytringer befinner seg i, må en gå til de systemiske sjanger- og diskursteoriene som kan beskrive dynamikk mellom mikro og makro (det vil si hvordan kontekst gir mening til tegn og ytringer).

- Hvilket som helst av de fem hovedaspektene er i prinsippet både en separat og en integrert del av en ytring i kontekst. Det betyr at en må veksle eller velge mellom kategoriell og relasjonell logikk og følgelig anvende en metodologi som kan håndtere denne dobbeltheten.

- I praksis tvinges en som forsker til å gjøre separate analyser av aspekter (av en helhet). Når flere ulike del-analyser ses i sammenheng, risikerer en at de er 'inkompatible' eller at de altså ikke uten 
videre kan 'summeres' til en gyldig helhet (den hermeneutiske sirkel). Avveiningene i en slik metodisk situasjon vil ligne studier som benytter seg av triangulering.

- Skal en se estetikk som integrert og/eller separat del av fag-/didaktikk? Svaret er kanskje. En har igjen å gjøre med en variant av den hermeneutiske sirkelen - en kan ikke, men må se bort fra estetikk, fordi det å ta et perspektiv eller ett perspektiv (estetisk, epistemologisk eller etisk) gjør vold på ytringens meningshelhet.

- Når maktforholdet mellom aspektene innbyrdes har skiftet gjennom tidene, og en historisk sett kan iaktta en systemisk sammenheng mellom aspektskiftene, hva er da egentlig en gyldig posisjon i slike paradigmeskifter? Dette spørsmålet leder i sin tur til spørsmålet om forholdet mellom ulike former for mening i ulike kultur- og samfunnsformer ('produksjonsforhold') og følgelig også om balanse eller avveining mellom relevans og gyldighet. Om en f.eks. anvender generelle begreper som premodernisme, modernisme og postmodernisme, finnes det da én eller flere gyldige posisjoner, og er faglige og vitenskapelige posisjoneringer som rendyrker et aspekt f.eks. formalisme, essensialisme, praktisisme og relativisme vitenskapsteoretisk sett ugyldige? Hvilken rolle spiller sjangrene?

- Når all læring i prinsippet ses som semiose, dvs. som betydningsendring vil endringen gjelde alle triadiske aspekter på én og samme gang. Slik sett er læring altså også en estetisk prosess i relasjonen estetikk - epistemologi - etikk. I dagens utdanningspolitiske situasjon, som i Norge preges sterkt av Nasjonalt kvalitetsrammeverk (NKR) og bruk av såkalte læringsutbyttebeskrivelser (LUB) er form og estetikk bevisst utelatt fra kunnskaps-, ferdighets- og kompetansebegrepet. Hvilke konsekvenser kan det få?

\section{Noen utfordringer for et dobbelt triadisk perspektiv på ytringer i kontekst}

- de ulike delene kan risikere å være inkonsistente (siden aspektene er av forskjellig 'natur')

- om hypotesen er generell kan en risikere å ende opp med banaliteter og uinteressante detaljer

- selv med et relasjonelt utgangspunkt er det fare for å tolke aspekter som sikre kategorier

- triadisk semiotiske analyser over tegnnivå er fortsatt lite utviklet, metodologisk sett

- detaljerte analyser er mer tids- og ressurskrevende og fordrer gode, skjerpede hypoteser

\section{Et dobbelt triadisk perspektiv på semiotiske ytringer i kontekst}

- tilbyr et (nødvendig?) rammeverk for (fag-)didaktiske studier og vitenskapsteori

- er i stand til å føre sammen teorier om 'selv', 'verden' og 'samfunn' (livsverden)

- kan anvendes som redskap til å forklare vekst og fall i kulturer og sub-kulturer

- kan fungere som referanseramme for utfordringen fra den hermeneutiske sirkelen

- åpner, i kombinasjon med ulike etablerte metoder, for spesifikk forskning

- er nyttig som grunnlag for komparative studier av kommunikasjon, kunnskap og kultur

- gir bedret tilgang til og mer differensierte studier av makt knyttet til sjangre og diskurser

- $\quad ø k e r$ forståelsen av sjangrenes og diskursenes mer subtile rolletildeling (posisjonering)

- kan brukes til (selv-)kritikk av ideologier (også rammeverkets eget relativistiske islett)

- er grunnleggende for å forstå institusjonell og livslang sosialisering i en videre kontekst

- er nødvendig for praktisk vurdering og teoretisk avveining av ulike former for gyldighet

- kan påvise sammenhenger mellom former for kommunikasjon og former for kunnskap

- kan gi økt tverr- og flerfaglig forståelse av utdanning, forskning og vitenskapsteori

- kan redusere et delvis kunstig skille mellom observasjon, forskning og publisering 
Rammeverket kan i prinsippet anvendes på mange didaktiske utfordringer, men selvsagt med ulike grader av relevans og gyldighet (Ongstad, 2013 a). Med vekt på en estetisk inngang til fagdidaktikk kan det semiotisk-kommunikative rammeverket, gjerne i kombinasjon med ulike former for posisjoneringsteori (Ongstad, 2007b), legges til grunn for analyser av en rekke ulike problemstillinger og utfordringer. Generelt kan en si at rammen kanskje særlig egner seg til å analysere faglig og didaktisk dominans eller $u$ /balanse mellom kommunikative trekk i dokumenter, læreplaner, lærebøker og undervisning. I min egen forskning er det de 10-15 siste årene f.eks. gjort en rekke større eller mindre, kvalitative, til dels kritiske studier av:

- skolens oppgavekultur mer generelt, med vekt på fagforskjeller (Ongstad, 1997)

- $\quad$ selvbiografiens (u-)balanse mellom selv, levd liv og (skrive-)handling (Ongstad, 1997)

- den estetiske dimensjonens betydning i én enkelt elevs selvposisjonering (Ongstad, 1999)

- utvikling av norsk og nordisk skriveforskning innen utdanningsfeltet (Ongstad, 2002)

- Prøysens Stil om katten med vekt på sjangerveksling og 'mening' (Ongstad, 2004/1996)

- kommunikasjonsformer og endring av samfunns- og meningsformer (Ongstad, 2004/1997)

- den estetisk-emosjonelle dimensjonens betydning i elevskriving (Ongstad, 2005)

- estetikkens potensielle plass i matematikk(-didaktikk) (Ongstad, 2004/2006)

- klasserommet som formforum, meningsunivers og handlingsarena (Ongstad, 1997/2007d)

- $\quad$ sjangre og vekting av estetikk, epistemologi og etikk i læreplaner (Ongstad, 2010)

- såkalt kjernefaglighet i relasjon til form-innhold-handling-tid-sted (Ongstad, 2012a)

- posisjoneringsanalysens metodologiske utfordringer (selvkritisk) (Ongstad, 2012b og 2013a)

Form- og estetikkaspektet er ivaretatt i så godt som alle studiene. I flere av analysene er det et hovedtema. Avslutningsvis og apropos - for tiden studerer jeg hvilke mulige didaktiske dysfunksjoner det begrensede sett av didaktiske hovedbegreper (kunnskap, ferdighet og generell kompetanse) i det nasjonale kvalifikasjonsrammeverket (NKR) kan ha. Her er fokus scerlig på mulig svekkelse av den estetisk-emosjonelle dimensjonen (og følgelig også av aspektet 'holdninger'. Artikkelen skal inngå i ei bok fra prosjektmiljøet The Didactic Challenge of New Literacies in School and Teacher Education og er knyttet til mitt eget del-prosjekt, Discursivity and Disciplinarity som bl.a. ser på forholdet mellom faglighet og språklighet mer generelt, men også mer spesifikt i læreplaner (Ongstad 2013b).

\section{Oppsummering}

En sentral hypotese har vært at kommunikasjon i bred forstand er grunnleggende for utvikling av natur og kultur - levende vesener er dømt til kommunikasjon. En semiotisk definisjon av kommunikasjon ser alle ytringer som tegn, og ytringer i natur og kultur vil derfor i prinsippet i det minste bestå av strukturert form, som kan ha referensielt innhold og en handlingsfunksjon. Alle fag og kunnskapsområder består av en mengde ytringer som vektlegger disse aspektene, men på forskjellig vis og i ulik grad. I tillegg vil repetetiv bruk av ytringer i kontekst over tid skape delvis gjenkjennbare og mer eller mindre stereotypiske former for kommunikasjon som vil kunne særprege fag, men også etablere fagslektskap. Slik etableres et dobbelt triadisk perspektiv på kulturelle ytringer. Tre hjørnesteiner (eller tre gjensidige aspekter om en vil) i menneskelig, faglig kommunikasjon vil derfor balansere mellom estetisk vurdering av form, epistemologisk vurdering av innhold og etisk vurdering 
av handling. Den innbyrdes relasjonen mellom disse kunnskapsteoretiske aspektene blir derfor helt sentral for alle fag. I innledningsdelen ble særlig aspektet estetikk drøftet noe mer inngående.

I neste del ble to tilnærminger, Eisner (1985) og Løvlie (1990), til relasjonsproblemet drøftet, vennlig kritisk, og med en pedagogisk/didaktisk kontekst for øye. En konklusjon var at et pragmatisk handlingsperspektiv må inkorporeres, ikke minst fordi det utgjør en bro over til spørsmålet om kontekst og til problemet med det innbyrdes forholdet mellom de grunnleggende aspektene. Både Eisner og Løvlie hadde imidlertid som utgangspunkt at estetikk var grunnleggende for kunnskap. Dette anliggende understøttes i konklusjonen og ble ført videre, dels summarisk, i neste del, nemlig på det etiske området.

Videre ble det fremholdt at lingvistikk vil utgjøre et for snevert utgangspunkt, og semiotikk ble lansert som en bredere, alternativ forståelsesramme. Det ble lansert sju krav til en modell, eller en referanseramme som tar mål av seg å analysere og fortolke kulturell kommunikasjon. Langt på vei innebærer et slikt perspektiv at semiotikk gjøres til en sentral del av kunnskaps- og vitenskapsteori som felt, og det følgende kapitlet konkretiserer og til dels problematiserer et slikt standpunkt. Svært forenklet vil altså et rammeverk for kulturelle ytringer måtte bestå av hovedaspekter som inngår i et relasjonelt system, snarere enn i umiddelbare, klart avgrensede kategorier. I en omfattende oversikt vises så en lang rekke sentrale aspektrelasjoner. Disse er relatert 'horisontalt' og 'vertikalt' som kommunikative triader, og de mest sentrale forbindelsene kommenteres og forklares. Det vises kort til kritikk, og det gjøres en punktvis evaluering av fordeler og ulemper med å anlegge "et dobbelt triadisk perspektiv på semiotiske ytringer i kontekst". Siden artikkelen mer isolert sett sikter mot teoriutvikling og teoriavklaring, vises det til slutt til ulike 'empiriske' studier som er gjort med utgangspunkt i ulike versjoner av rammeverket de 10-15 siste årene.

Selv om en viktig hensikt med artikkelen har vært å presentere den grunnleggende kunnskapsteoretiske betydningen av relasjonen mellom estetikk, epistemologi og etikk, så har hovedhensikten mer generelt vært å åpne for et semiotisk-kommunikativt perspektiv på estetikk og utdanning. Det er likevel ikke en analysemodell som presenteres. Studier med basis i rammeverket må operasjonaliseres i underkategorier som den enkelte forsker eller det enkelte prosjekt selv utvikler.

\section{English abstract}

This theoretical article aims at revealing intrinsic relationships, on the one hand, between a series of different communicational and didactic aspects grouped under the three key concepts aesthetics, epistemology and ethics. On the other hand it is claimed that the internal dynamics between form, content and act in any cultural utterance in principle is at the core of a series of well-known conceptual triads in both philosophy and education. Although the text mainly argues on a general level by bringing together theoretical views from various sources, it also leans on years of empiric research in the field, investigating different aspects of teaching, knowledge and learning. Even if the main focus is on the relationship between the two mentioned triads, particular attention is also paid to how aesthetics relates to communication, especially in education and (disciplinary) didactics. It proceeds by first clarifying crucial concepts and their reciprocal and problematic nature. It further presents and discusses briefly two important texts in the field of education that have wrestled with these relationships. Additionally, it is argued that for understanding the triads' impact on researchers' disciplinarity, the overall scope should be extended from linguistics to semiotics. The last part establishes and explains a systematised overview of key triads. Finally, this simplified framework is 
evaluated, and supplemented by short references to a series of specific studies of triadic issues over the past 15 years before summarising main ideas and arguments.

\section{Forfatterpresentasjon}

Sigmund Ongstad er professor i fagdidaktikk ved masterstudiet i Utdanningsvitenskap ved Høgskolen i Oslo og Akerhus. På 70-tallet arbeidet han mest med læreplan- og differensieringsproblematikk, på 80-tallet skriveforskning og fagdidaktikk og på 90-tallet skolens oppgavekultur og sjangerteori. Sentrale publikasjoner fra senere år omfatter bl.a. bøkene Språk, kommunikasjon og didaktikk (2004), Fag og didaktikk i loererutdanning (red.) (2006) og Nordisk morsmålsdidaktikk (red.) (2012). Hans nåværende forskningsfokus er forholdet mellom Discursivity and Disciplinarity, et delprosjekt i NFRprosjektet The Didactic Challenge of New Literacies in School and Teacher Education.

\section{Referanser}

Bakhtin, M. (1986). Speech Genres and Other Late Essays. Austin: University of Texas Press.

Barthes, R. (1977). Elements of Semiology. New York: Hill and Wang.

Baumann, Z. (1995/1993). Postmodern etik. Göteborg: Daidalos.

Bazerman, C., Bonini, A. \& Figueiredo, D. (2009). Genre in a Changing World. The WAC Clearinghouse.

Ben-Amos, D. (1969). Analytical Categories and Ethnic Genres. Genre. 2/3:275-301.

Bense, M. (1977). Pädagogische Intentionen in der Semiotik. I H. Brög (red.) Probleme der Semiotik under dem schulischen Aspekt. Ravensburg: O. Maier.

Berge, K. L. (o. a.) (1998). A skape mening med språk. En samling artikler av M.A.K. Halliday, $R$. Hasan og J.R. Martin. Oslo: LNU/Cappelen Akademisk.

Bourriaud, N. (2007). Relasjonell estetikk. Oslo: Pax Forlag.

Braathe, H. J. (2010). Communicative positionings as identifications in mathematics teacher education. I: Proceedings of CERME 6. Proceedings of the Sixth Congress of the European Society for Research in Mathematics Education. January 28th - February 1st 2009, Lyon (France). Institut National de Recherche Pedagogique, s. 925-933.

Braathe, H. J. Discursive positioning in Norwegian teacher education: Shifting from crosscurricularity to skills based subject specialisation. International Journal of Educational Research, Vol 55, 2012, ss 26-35

Bühler, K. (1934/1965). Sprachtheorie. Stuttgart: Fischer.

Cunningham, D. J. (1987).: Outline of an Education Semiotic. The American Journal of Semiotics, Vol. 5, No.2. 1987.

Eco, U. (1976). A theory of semiotics. Bloomington: Indiana University Press.

Eisner, E. (1985). The Art of Educational Evaluation. London: Falmer.

Elf, N. F. (2009). Towards semiocy? Exploring a New Rationale for Teaching Modes and Media of Hans Christian Andersen Fairytales in Four Commercial Upper-Secondary "Danish" Classes: A Design-Based Educational Intervention. Ph.d.-afhandling. Det humanistiske fakultet. Syddansk Universitet.

Fairclough, N. (1992). Discourse and Social Change. Cambridge, UK: Polity Press.

Finnegan, R. (2002). Communicating: The Multiple Modes of Human Interconnection. London: Routledge.

Flannery, M. (1991). Science and aesthetics. A partnership for science education. Science Education, 75(5), ss 577-593. http://dx.doi.org/10.1002/sce.3730750507 
Goldman, A. (2001). The Aesthetic. I Gaut, B. og Lopes, D. M. (red.) The Routledge Companion to Aesthetics. London: Routledge.

Gardner, H. (1997). Truth, Beauty, and Goodness: Education for All Human Beings. A Talk With Howard Gardner. Intervju: J. Brochman. http://www.edge.org/3rd_culture/gardner/gardner_p1.html

Gaut, B. og Lopes, D. M. (red.) (2001). The Routledge Companion to Aesthetics. London: Routledge. http://dx.doi.org/10.4324/9780203390795

Grant, C. (2007). Uncertainty and Communication. New Theoretical Investigations. London: Palgrave. http://dx.doi.org/10.1057/9780230222939

Habermas, J. (1988). Kommunikativt handlande. Texter om språk rationalitet och samhälle. Göteborg: Daidalos.

Halliday, M. A. K. (1978). Language as social semiotic. London: Arnold.

Halliday, M. A. K. (1994). An Introduction to Functional Grammar. Second Edition. London: Arnold.

Hansen, N. B. (2002). Pcedagogikkens Treklang. Et opgør med dualismen i dansk skoletcenkning. København: Gyldendal Uddannelse.

Harré, R. (1980). Social Being. Totowa: Rowman and Littlefield.

Harré, R. (1984). Personal Being. Cambridge: Harvard University Press.

Harré, R. (1991). Physical Being: Oxford: Blackwell.

Hausken, L. (2009). Medieestetikk: studier i estetisk medieanalyse. Oslo: Universitetsforlaget.

Hernadi, P. (1995). Cultural Transactions. Nature, Self, Society. Ithaca: Cornell University Press.

Hertzberg, N. (1898). Opdragelse og undervisning. Kristiania (Oslo): Grøndahl.

Hiim, H. og Hippe, E. (1998). Laering gjennom opplevelse, forståelse og handling. Oslo:

Universitetsforlaget.

Hoffmeyer, J. (1994). Livets tegn. Oslo: Gyldendal.

Hohr, H. J. (2012). Aesthetic quality in scientific experience. The problem of reference in John Dewey's aesthetics. Nordic Studies in Education, 32, ss. 196-208.

Honderich, T. (red.) (1985). Morality and Objectivity. London: Routledge.

Illeris, K.(1999). Loering - aktuell loeringsteori i spenningsfeltet mellem Piaget, Freud og Marx.

Roskilde: Roskilde Universitetsforlag.

Imbert, P. (1980). Multidisciplinarity, semiotics, and pedagogy. Ars semeiotica, 3:275-81.

Jensen, K. B. (1995). The Social Semiotics of Mass Communication. London: Sage.

Kant, I. (1987/1790). Critique of Judgement. Indianopolis: Hackett Publishing Company.

Kattenbelt, C. (1994). The triad of emotion, action and reflection. A sign-pragmatic approach to aesthetic communication. Ars Semeiotica, vol. 17, no1/2, s.123-139.

Kelly, M. (red.) (1998). Encyclopedia of Aesthetics. Oxford: Oxford University Press.

Kjørup, S. (1999). Baumgarten og den sensitive erkendelse. I Holmgaard, J. (red.) AEstetik og logik, ss. 41-60. Ålborg: Center for Æstetik og Logik/Medusa.

Klafki, W. (2001). Dannelsesteori og didaktik-nye studier. Århus: Klim.

Kragh, H. (1999). Det smukke og det sanne. I Holmgaard, J. (red.) Astetik og logik, ss. 211-234. Ålborg: Center for Æstetik og Logik/Medusa.

Kress, G. (2010). Multimodality. A social semiotic approach to contemporary communication.London: Routledge.

Leksikon for det 21. århundrede (2013). Æstetik. I Leksikon for det 21. århundrede http://www.leksikon.org/art.php?n=712 [Forfatter Jan Brochmann.] (Besøkt 19.02.2013). 
Levinson, J. (1998). Introduction: aesthetics and ethics. I Levinson, J. (red.) Aesthetics and Ethics. Essays in the Intersection, ss. 1-25. Cambridge: Cambridge University Press. http://dx.doi.org/10.1017/CBO9780511663888

Lindström, L. (2009). Mediated Action and Aesthetic Learning. Themes in Swedish Studies 19952008. I Lindström, L. (red.) Nordic Visual Arts Education in Transition A Research Review, ss: 52-79. Stockholm:Vetenskapsrådet.

Lundgren, U. P. (red.), Uttryck, intryck, avtryck: lärande, estetiska uttrycksformer och forskning (2006:4, pp. 107-122). Stockholm: Vetenskapsrådet.

Løvlie, L. (1990). Den estetiske erfaring. Nordisk pedagogik. 1-2.

Madsen, P. (1971). Semiotik og dialektik. København: Munksgaard.

Martin, J. (1997). Analysing genre: functional parameters. I Christie, F. og J. Martin (red.) Genre and Institutions. London: Cassell.

Mellin-Olsen, S. (1991). Hvordan tenker loerere om matematikkundervisning? Landås, Bergen: Bergen LHS.

Miller, C. R. (1984). Genre as social action. Quarterly Journal of Speech. 70:151-67. http://dx.doi.org/10.1080/00335638409383686

Morris, C. (1938/1970). Foundations of the Theory of Signs. Chicago: Chicago University Press.

Nöth, W. (1990). Handbook of Semiotics. Bloomington: Indiana University Press.

O'Hear, A. (red.) (2000). Philosophy, the Good, the True and the Beautiful.Cambridge: Cambridge University Press.

Ongstad, S. (red.) (1996). Hva vil vi med sjangrene - og de med oss. Oslo: Landslaget for norskundervisning og Cappelen Akademisk Forlag.

Ongstad, S. (1997). Sjanger, posisjonering og oppgaveideologier. Et teoretisk-empirisk bidrag til et tverrfaglig, semiotisk og didaktisk sjangerbegrep. Avhandling for graden dr. art ved NTNU, Trondheim 1997. Universitetet i Tronheim, Hist.-Fil.

Ongstad, S. (1999a). (Post-)moderne selvposisjonering og didaktikk. Om semiotiske tegntriader som didaktisk og vitenskapsteoretisk utfordring. I K.W. Møller (red.) Rapport fra uddannelseskonferanse, Århus. Jydsk Pædagog-Seminarium, Århus.

Ongstad, S. (1999b). Vad är positioneringsanalys? I C. A. Säfström og L. Östman (red.): Textanalys. Enintroduktion til syftesrelaterade analyser. Lund: Studentlitteratur.

Ongstad, S. (2002a). Genres - from static, closed, extrinsic, verbal dyads to dynamic, open, intrinsic,semiotic triads. I R. Coe et al. (red.) The Rhetoric and Ideology of Genre: Strategies for Stability and Change.Hampton Press.

Ongstad, S. (2002b). Positioning Early Norwegian Research on Writing. Written Communication, 19/3. http://dx.doi.org/10.1177/074108802237749

Ongstad, S. (2004a). Språk, kommunikasjon og didaktikk. Oslo: LNU/Cappelen.

Ongstad, S. (2004b). Fagdidaktikk som forskningsfelt. I Norges forskningsråd: Kunnskapsstatus for forskningsprogrammet KUPP. Oslo: NFR.

Ongstad, S. (2004c). Bakhtin's triadic epistemology and ideologies of dialogism. I Bostad, F, Brandist, C., Evensen, L. S. \& Faber, S. (red.) Bakhtinian perspectives on language and culture. London: Palgrave Macmillan.

Ongstad, S. (2005). Enculturation to institutional writing. I T. Kostouli (red.) Writing in Context(s). N.Y: Springer.

Ongstad, S. (red.) (2006a). Fag og didaktikk i loererutdanning. Kunnskap i grenseland. Oslo: Universitetsforlaget. 
Ongstad, S. (2006b). Mathematics and Mathematics Education - Language and/or Communication? TriadicSemiotics Exemplified. Educational Studies in Mathematics. 61/1.

Ongstad, S. (2007a). The Concepts of 'Language' and 'Discipline' in Transgression. I Martyniuk, W. (red.) Towards a Common European Framework of Reference for Language(s) of School Education? Krakow: Universitas.

Ongstad, S. (2007b). "Positioning in Theory. A methodological framework for MTE-studies and beyond". In W. Herrlitz; S. Ongstad and P. H. van de Ven (eds.) MTE Methodologies in international and comparative perspective. Amsterdam/NY: Rodopi.

Ongstad, S. (2007c). "Positioning in/of Practice. On communication and validation". I W. Herrlitz; S. Ongstad og P. H. van de Ven (red.) MTE Methodologies in international and comparative perspective. Amsterdam/ NY:Rodopi.

Ongstad, S. (2007d). "Research on and in Classrooms. Communicative and methodological perspectives on MTE-lessons as embodied. Trends and tendencies in classroom research". I W. Herrlitz; S. Ongstad og P. H. van de Ven (red.) MTE Methodologies in international and comparative perspective. Amsterdam/NY: Rodopi.

Ongstad, S. (2009). The Concept of Lifeworld and Education in Post-Modernity. I Murphy, M. og Fleming, T. (red.) Habermas, Critical Theory and Education. London: Routledge, s. 47-62.

Ongstad, S. (2010). "Synchronic-diachronic Perspectives on Genre Systemness: Exemplifying Genrification of Curricular Goals." I S. Kvam (red.) Genre and Cultural Competence: An Interdisciplinary Approach to the Study of Texts. Berlin: Waxmann, s. 35-50.

Ongstad, S. (2012a). Komparativ fagdidaktikk? Eksempler, hypoteser og forutsetninger. I CURSIV nr. 9:33-50

Ongstad, S. (2012b). Fra kunnskap, via kontekst, kjerne og komparasjon til kommunikasjon. En fagdidaktisk utviklingslinje? Nordidactica - Journal of Humanities and Social Science Education Nr. 2 (http://kau. diva-portal.org/smash/record.jsf?pid=diva2:417293)

Ongstad, S. (2012c). Rolle, stemme og posisjonering mellom begrepsvaliditet og bruksrelevans. I Matre, S., Sjøhelle, D. K. og Solheim, R. (red.) (20012. Teorier om tekst i møte med skolens leseog skrivepraksiser, s. 33-47. Oslo: Universitetsforlaget.

Ongstad, S. (2013a). Dynamisk kontekst og pragmatisk validitet som metodologisk utfordring for morsmålsdidaktisk forskning. I Skjelbred, D. og Veum, A. (red.) Literacy i lceringskontekster. Oslo: Cappelen Damm.

Ongstad, S. (2013b). Discursivity and Disciplinarity: Literacies and/as semiotics across curricula. Prosjektbeskrivelse: http://blogg.hioa.no/literacy/reports/sigmund-ongstad/.

Peirce, C. S. (1940/65). Collected Papers. Cambridge, Mass.: Belknep Press.

Peirce, C. S. (1994). Semiotik og pragmatisme. København: Gyldendal.

Pluhar, W. (1987). Translator's Introduction. I Kant, I.: Critique of Judgement. Indianopolis: Hackett Publishing Company, s. xxiii-cix.

Rørvik, H. (1998). Didaktisk refleksjon. Oslo: Universitetsforlaget.

Saussure, F. de (1916/1974). Course in General Linguistics. (Ved. J. Culler.) London: Fontana. Saussure, F. de (1983). Course in General Linguistics. Peru, Illinois: Open Court Classics. Sebeok, T. (1991). A sign is just a sign. Bloomington: Indiana University Press.

Smidt, J. (2007). Positioning, responsibility, and relevance in MTE research. I: Herrlitz, W.; Ongstad,S.; Ven, P. v. d. (red.) Research on MTE in a comparative international perspective theoretical and methodological issues. Amsterdam/New York, NY : Rodopi, ss 211-226. 
Smidt, J. (2008). Dialoger og posisjoneringer - felt, relasjon, mediering. Utprøving av hallidayske og bakhtinske begrep i analyse av elevtekster og skrivesituasjoner i skolerelevant forskning. FoU $i$ praksis, 2 (1) s. 23-46.

Steiner, R. (1927). Truth, Beauty and Goodness. London: Anthropological Publishing Company.

Stjernfelt, F. og Thyssen, O. (red.) (2000). Astetisk kommunikation. København: Handelshøjskolens Forlag.

Svendsen, L. og Säätelä, S. (2004). Det sanne, det gode og det skjønne. En innføring i filosofi. Oslo: Universitetsforlaget.

Sørensen, H. M. (1999). Viden eller æstetik. I Holmgaard, J. (red.) AEstetik og logik, s. 61-80. Ålborg: Center for Æstetik og Logik/Medusa.

Thavenius, J. (2002). Estetik och skola. Några synpunkter på forskningsläget I L. Aulin-Gråhamn (red.), Kultur, estetik och skola. Några forskningsperspektiv (Rapporter om utbildning, 2002:9, pp. 43-66): Malmö Högskola: Lärarutbildningen.

Threadgold, T. (1986). The semiotics of Vološinov, Halliday, and Eco. American Journal of Semiotics, Vol. 4, Nr. 3-4, s. 107-142. http://dx.doi.org/10.5840/ajs198643/423

Thielst, P. (2001). Det sande, det gode og det skønne. Erkendelsesteori, etik og cestetik. En indføring $i$ filosofi.Fredriksberg (København): Det lille forlag.

Wicks, R. (2001). Foucault. I Gaut, B. og Lopes, D. M. (red.) The Routledge Companion to Aesthetics, s. 143-154. London: Routledge. 